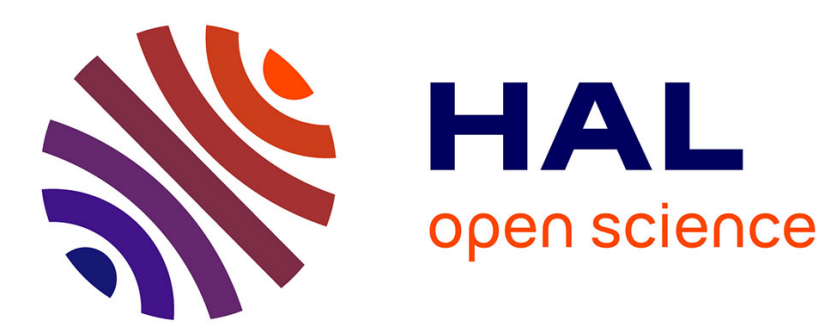

\title{
Map view retrodeformation of an arcuate fold-and-thrust belt: The Jura case.
}

\author{
T. Affolter, Jean-Pierre Gratier
}

\section{To cite this version:}

T. Affolter, Jean-Pierre Gratier. Map view retrodeformation of an arcuate fold-and-thrust belt: The Jura case.. Journal of Geophysical Research: Solid Earth, 2004, 109 (B3), pp.B03404. 10.1029/2002JB002270 . hal-00109362

\section{HAL Id: hal-00109362 \\ https://hal.science/hal-00109362}

Submitted on 1 Feb 2021

HAL is a multi-disciplinary open access archive for the deposit and dissemination of scientific research documents, whether they are published or not. The documents may come from teaching and research institutions in France or abroad, or from public or private research centers.
L'archive ouverte pluridisciplinaire HAL, est destinée au dépôt et à la diffusion de documents scientifiques de niveau recherche, publiés ou non, émanant des établissements d'enseignement et de recherche français ou étrangers, des laboratoires publics ou privés. 


\title{
Map view retrodeformation of an arcuate fold-and-thrust belt: The Jura case
}

\author{
Thomas Affolter ${ }^{1,2}$ and Jean-Pierre Gratier \\ Laboratoire de Géophysique Interne et de Tectonophysique, Université Joseph Fourier, Grenoble, France
}

Received 28 October 2002; revised 15 September 2003; accepted 21 November 2003; published 9 March 2004.

[1] The mechanism of arcuate mountain range formation is a matter of debate. Here we perform a map view restoration of a detailed three-dimensional model of the Jura arc, a typical arcuate mountain range in the foothills of the Swiss and French Alps. This retrodeformation is performed using the UNFOLD surface-balanced program, based on a "block mosaic" method. It results in a displacement field divergent toward the deformation front. This displacement field suggests counterclockwise rigid rotations in the horizontal plane up to $30^{\circ}$ in the southern Internal Jura and a corresponding vertical axis rotation or shear strain of the Savoie molasse basin hinterlandward. We also predict a $10^{\circ}$ clockwise, vertical axis rotation of the molasse basin in Switzerland. All these rotations agree with those documented by paleomagnetic data. The former are taken to result from a substantial decrease in shortening at the southern Jura end, while the divergence of displacements is interpreted to result from variations in the detachment level distribution. INDEX TERMS: 8102 Tectonophysics: Continental contractional orogenic belts; 8122 Tectonophysics: Dynamics, gravity and tectonics; 8005 Structural Geology: Folds and folding; 8010 Structural Geology: Fractures and faults; 1525 Geomagnetism and Paleomagnetism: Paleomagnetism applied to tectonics (regional, global); KEYWORDS: displacement field, fold-thrust belt, restoration, unfolding, Jura, Alps

Citation: Affolter, T., and J.-P. Gratier (2004), Map view retrodeformation of an arcuate fold-and-thrust belt: The Jura case, J. Geophys. Res., 109, B03404, doi:10.1029/2002JB002270.

\section{Introduction}

[2] Understanding the pattern of strain over large areas and in various tectonic settings is a long-standing challenge. In recent years, the use of earthquake data combined with space-based GPS geodesy gave us new insight into active deformation processes. However, on the timescales of the existing earthquake and GPS records, an unknown component of transient deformation occurs. Our knowledge of this will only improve as records extend over timescales of at least several earthquake cycles. It is interesting therefore to compare displacements on a geologic timescale, where transient components are insignificant, with short-term velocity fields [Gratier et al., 1999; Hindle et al., 2002]. This is especially true in regions where strain rates are low. In this context the map view retrodeformation of geological structures provides a means of determining displacement fields in a geological time frame.

[3] Various methods have been proposed to determine the displacement field associated with a deformed area. Heterogeneous deformation can be estimated by dividing the study area into homogeneous domains, then by restoring and best fitting individual domains to obtain the initial undeformed

\footnotetext{
${ }^{1}$ Also at Institut Français du Pétrole, Rueil-Malmaison, France.

${ }^{2}$ Now at Boudry, Switzerland.
}

Copyright 2004 by the American Geophysical Union. 0148-0227/04/2002JB002270\$09.00 state [Cobbold, 1979; Oertel, 1974; Schwerdtner, 1977]. Applications of this method are given by Cobbold and Percevault [1983] and Gratier et al. [1989]. The "block mosaic technique" is another method which divides a folded and faulted surface into patches along fault cuts, then unfolds the patches and refits them to remove the throws associated with faults. Two versions of the block mosaic method exist. On one hand pseudo-three-dimensional methods are based on the linkage of a series of cross sections retrodeformed separately along the strike of the mountain range [Wilkerson et al., 1991]. It assumes the displacement direction is known a priori and is constant. This method is appropriate where structures are cylindrical for long distances and where cross-strike structures (fold curvatures and terminations) occur due to unidirectional transport over lateral/oblique ramps. The second type of block mosaic restoration techniques is based on three-dimensional (3-D) retrodeformation and is free of any assumption on the displacement field. For instance, in the case of the UNFOLD surface-balanced program [Gratier and Guillier, 1993; Gratier et al., 1991] (see section 3.2.1), the displacement field is uniquely determined provided that the surface being unfolded was originally folded through flexural slip, which is mostly associated with low-temperature deformation of layered rocks where strain is primarily accommodated by slip on stratigraphic interfaces. Surfaces folded through flexural slip are termed developable [Hilbert and Cohn-Vossen, 1952; Ramsay and Huber, 1983]. The lines in the plane of such surfaces are no- 
stretch lines and the total or Gaussian curvature should everywhere be equal to zero. The developable character of naturally deformed surfaces depends also on the scale of deformation considered. A surface may appear nondevelopable because of pervasive shear strain not seen at a regional scale. Faults responsible for internal deformation may be observed at a more local scale and on this basis the surface can be divided into several developable patches. The 3-D retrodeformation method is a way of quantifying the strike-parallel extension which must exist at the scale of the whole set of patches wherever the displacement field associated with a geological structure is not uniform. This longitudinal extension is directly related to the displacement field which generated the arcuate fold-thrust belt and which can be used to characterize the arc forming mechanism (see section 5.1). Three-dimensional restoration techniques are the only possible way to take this extension into account when determining the spatial distribution of bulk deformation, and are therefore central to our understanding of the formation mechanism of arcuate geological structures. In the present paper, a 3-D retrodeformation of the Jura, a typical curved fold-thrust belt at the front of the western Alps, is carried out.

\section{Geological Setting}

[4] The Jura is a typical foreland fold-thrust belt, where deformations involve a relatively thin sedimentary cover ( $\cong 2 \mathrm{~km}$ thick in the Internal Jura) deformed above a basal décollement in Middle and Upper Triassic evaporites (Figure 1). The Jura belt formed in the latest stage of the Alpine orogeny, between upper Miocene and lower Pliocene times, at the front of the Alpine foredeep [Affolter, 2003; Becker, 2000]. The idea of a regional detachment of part of the sedimentary cover above ductile evaporites, initially proposed by Buxtorf [1907, 1916], was confirmed by drill hole data and petroleum seismic lines and led to the now generally accepted thin-skinned model of deformation [e.g., Laubscher, 1961, 1965; Philippe, 1995; Sommaruga, 1995]. The five cross sections of Figure 2 compiled and completed after Chauve et al. [1988a], Donzeau et al. [1997], Enay [1982], and Philippe [1995] illustrate the style of deformation in the Jura. They are constrained by surface observations, well data and seismic lines. All show a detached and folded cover above the gently SE dipping basement top. By contrast with the deformed Jura cover, the molasse fill of the foreland basin was left virtually undeformed by Alpine deformations, although a distributed deformation of the molasse basin cannot be discounted. Therefore the molasse basin is believed to have been transported passively above the regional detachment, in the hanging wall of the most internal Jura thrusts (Figure 2c). In front of the foredeep basin, the progressive thinning of the molasse sediments reduced the confining pressure in the underlying Mesozoic cover and this enabled its deformation through a variety of folding mechanisms: detachment-induced box folds mainly found east of the study area [Laubscher, 1965], ramp folds in the Internal Jura and "Faisceaux" Jura [Philippe, 1995; Sommaruga, 1995] (Figure 2c) and evaporite anticlines essentially found in the Molasse basin and in the Jura "Plateaux" [Sommaruga, 1995] (Figures 2a and 2b). Major strike-slip faults (La
Tourne-La Ferrière, Pontarlier, Morez, Vuache, Culoz faults, etc. (Figure 1)) interrupt the lateral continuity of folds. Geological maps show that no clear crosscutting relationships exist between folds and strike-slip faults [Homberg et al., 1997; Laubscher, 1972; Tschanz and Sommaruga, 1993]. Strike-slip faulting was coeval with folding and these strike-slip faults should be considered as primary tear faults, as defined by Dahlstrom [1970].

[5] The Jura Plateaux are hardly deformed, flat-lying areas [e.g., Chauve et al., 1980]. They are separated by narrow zones of highly strained rocks, some of which are transpressive fault zones [Chauve and Perriaux, 1974]. Closely spaced low-amplitude folds separate the frontal Jura thrust from the Jura Plateaux (Figures $2 \mathrm{a}$ and $2 \mathrm{~b}$ ), or from the Internal Jura in the southwest where plateaus are lacking (Figures $2 \mathrm{c}$ and $2 \mathrm{~d}$ ). The short wavelength of these folds, clear on Figure 2c, is thought to be due to the reduced thickness of sediments involved in deformation in this external area. This reduced thickness is due to a period of peneplanation thought to have lasted from Late Cretaceous times to the onset of Jura deformation in upper Miocene. The only remnants of this period of erosion are Eocene lateritic paleosoils in karst pockets and Oligocene conglomerates [e.g., Alabouvette et al., 1984]. The Jura Faisceaux fringing the outer rim of the Jura arc formed in two stages. In the Oligocene, this region experienced normal faulting synchronous with formation of the Bresse Graben [Chauve et al., 1988a]. Industry seismic lines and wells show that Oligocene extension was concentrated in a narrow fault zone mainly visible on Figures $2 \mathrm{c}$ and $2 \mathrm{~d}$. Well data show that the basement (including Permo-Carboniferous sediments) southeast of this fault zone is almost not affected by Oligocene extension, except in the case of Figure 2c. Thus in the Jura Faisceaux, extension is only found as minor offset normal faults. Later the upper Miocene to early lower Pliocene Jura deformations reactivated these extensional structures [Chauve et al., 1988a] which probably played a role in the distribution of thrusts. At that time the frontal Jura was thrust above the eastern border of the Bresse graben. The limits of the Jura frontal thrust on top of the Bresse Neogene fill are determined from well data and the thrust displacement reaches $6 \mathrm{~km}$ in places [Chauve et al., 1988a; Michel et al., 1953].

\section{Methods}

\subsection{Construction of the 3-D Model}

\subsubsection{Definition of the Restoration Limits}

[6] First boundaries for the retrodeformation were defined, such that restoration relative to an assumed fixed reference line would integrate deformations consistent for a given time frame. The frontal Jura thrust over the Bresse depression (Figure 1) was chosen as a pin line. The definition of a hinterland boundary for the model is more problematical. The definition of an inner boundary east of the Vuache fault (Figure 1) is based on the assumption that the formation of the innermost folds was synchronous in this area. South of these folds, the molasse basin is only slightly folded above salt pillows in Keuper beds and therefore it can be regarded as the inner limit of Jura deformations. The next major deformations hinterlandward are found in the thrust molasse (Figure 1). Shortening in the 


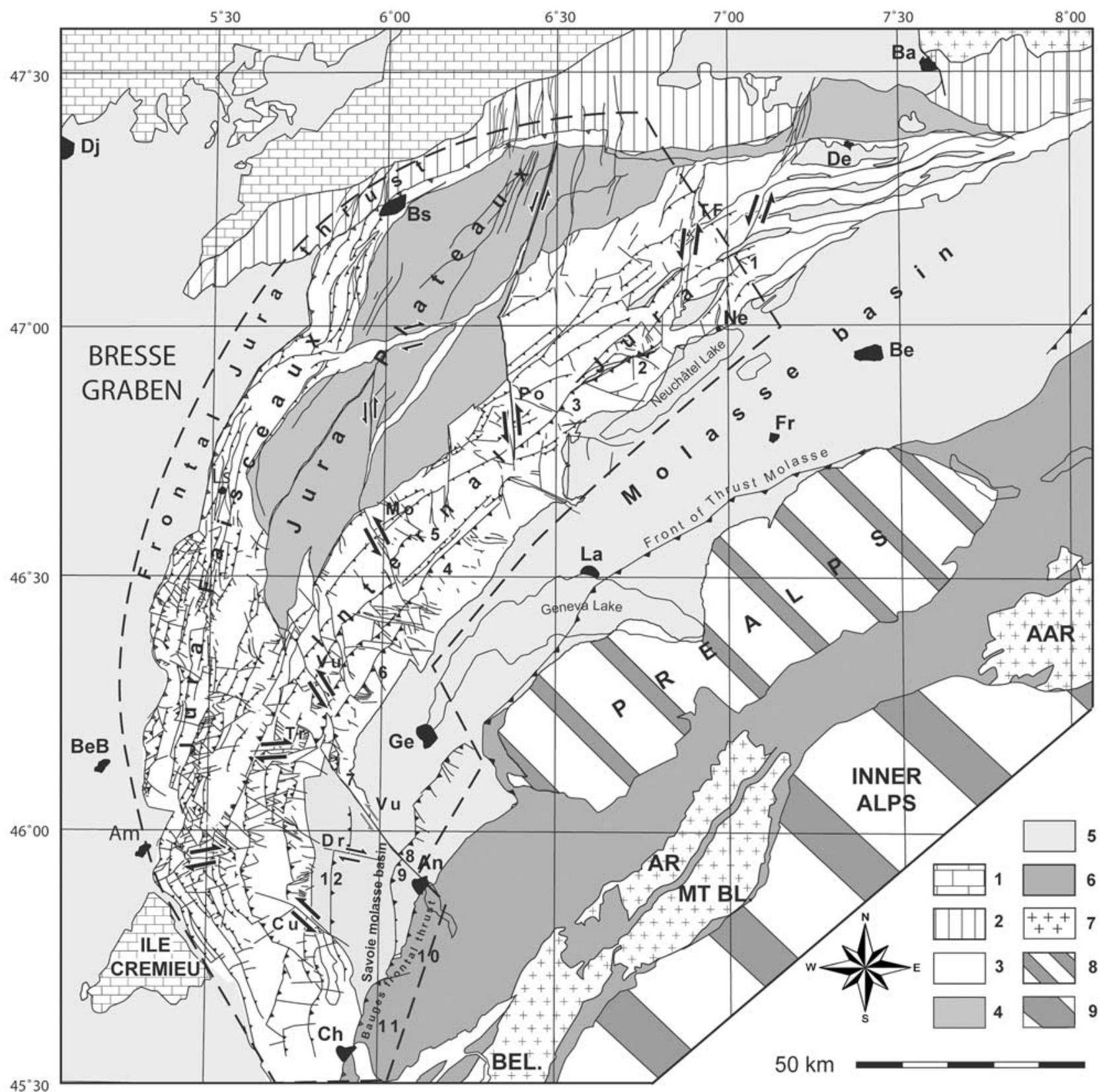

Figure 1. Geological and fault map of the Jura arc. Folds are not represented. Black dashed line is limit of the study area. Major strike-slip faults: 1, autochtonous Mesozoic cover of the Bourgogne plateform; 2, para-autochtonous Mesozoic cover of the Avant-Monts zone and Tabular Jura; 3-4, Jura fold-thrust belt (3, Internal Jura and imbricate zones of the "Faisceaux," and 4, Jura Plateaux); 5, Cenozoic fill of the Bresse-Rhine grabens and foreland molasse basin; 6-7, subalpine domain (6, Mesozoic cover, and 7, Paleozoic basement (BEL, Belledonne; AR, Aiguilles-Rouges; MT BL, Mont-Blanc); 8, pre-Alps; 9, Inner Alps. Major strike-slip faults: TF, La Tourne-La Ferrière; Po, Pontarlier; Mo, Morez; Vu, Vuache; Tr, Trébillet; Cu, Culoz; Mn, Montagny; Dr, Droisy. Anticlines: 1, Chasseral; 2, Boudry; 3, Chasseron; 4, Mount Tendre; 5, Risoux; 6, Crêt de la Neige; 7, Mont Vuache; 8, Mandallaz; 9, Montagne d'Age; 10, Semnoz; 11, Revard; 12, Gros-Foug. Towns: Am, Ambérieu-en-Bugey; An, Annecy; Ba, Basel; Be, Besançon; BeB, Bourg-en-Bresse; Ch, Chambéry; Fr, Fribourg; Ge, Geneva; La, Lausanne; LS, Lons-le-Saunier; Ne, Neuchâtel.

thrust molasse is difficult to quantify but should be less than $10 \mathrm{~km}$ [Burkhard and Sommaruga, 1998]. The timing of deformation of the thrust molasse is badly constrained in western Switzerland because the youngest sediments have been removed by erosion. In eastern Switzerland, sediments involved in thrusting indicate that it is of a lower Miocene age (M. Burkhard, oral communication, 2002). For this reason, displacements associated with the thrust molasse 
$\ddot{w}$
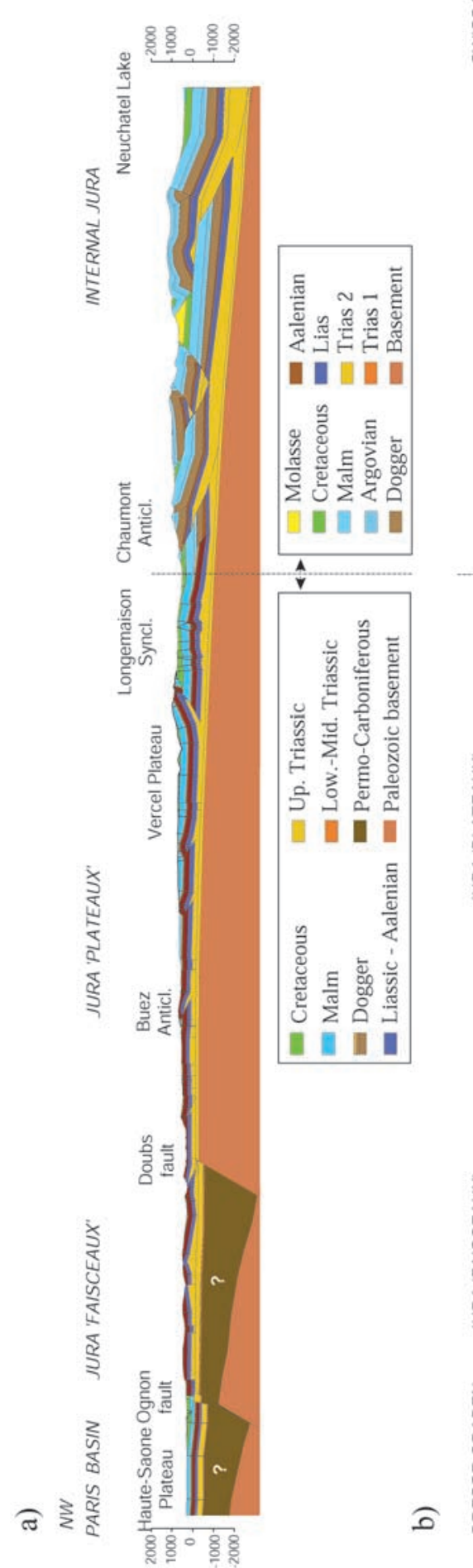

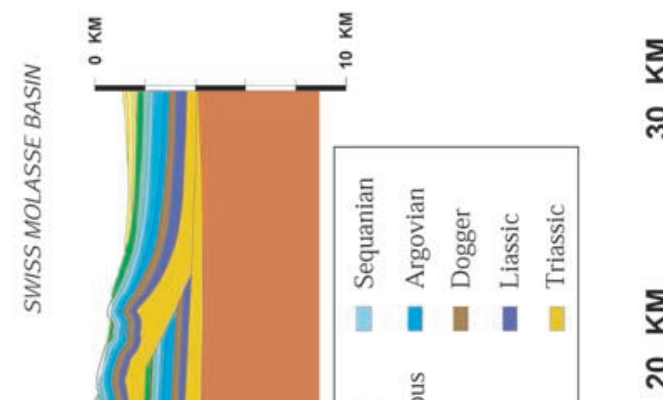

ई

$\xi$

กิ

도

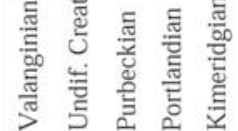

$>5$ 家

| | || ||

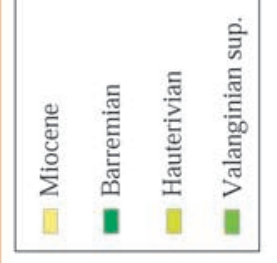

이니

I

ริ

D.

뭉

플

䒿

을

$\frac{n}{2}$

ปี

$\overline{0}$

छ.

용

\begin{tabular}{ll}
\hline \\
0
\end{tabular}

空范

. 율

远

$\stackrel{9}{9}$

0,0

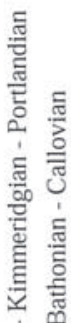

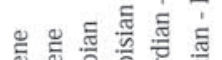




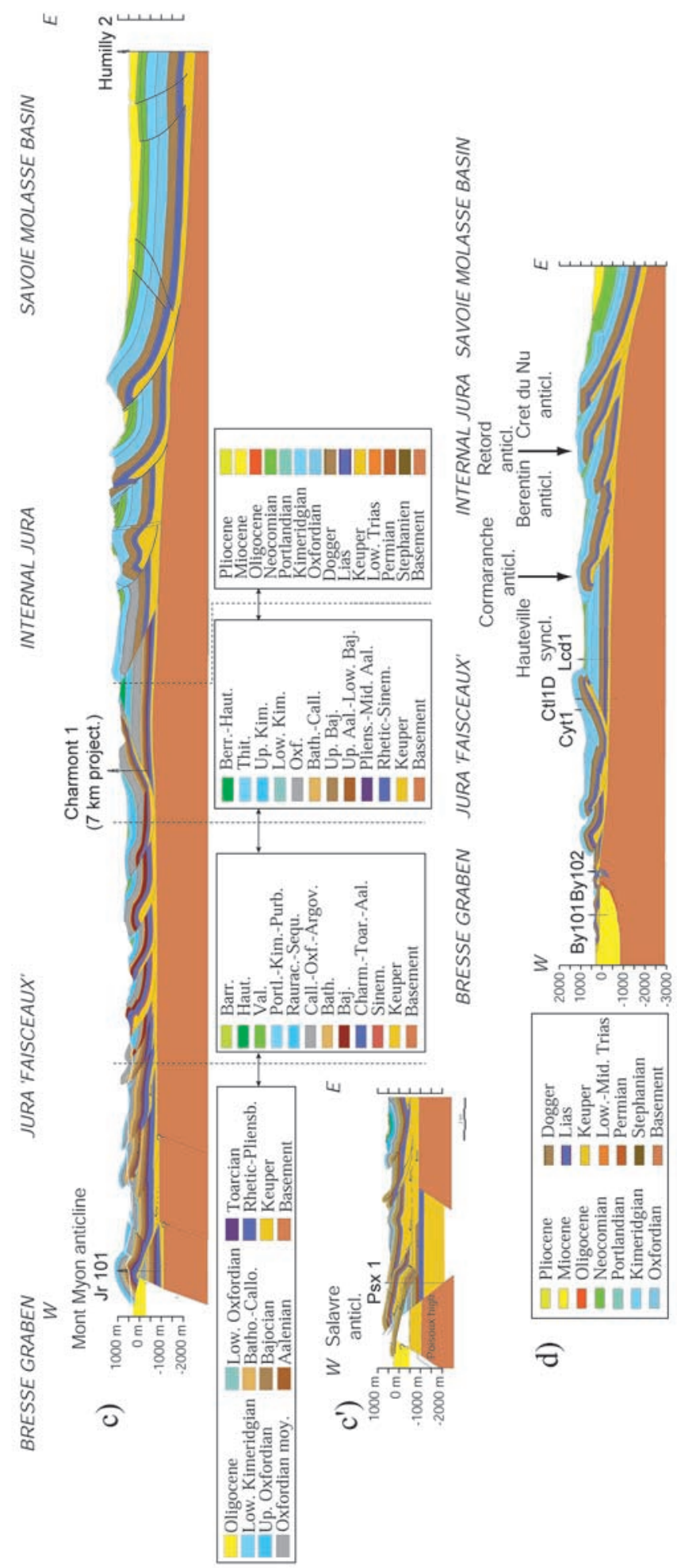

s
ol

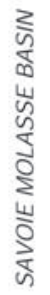

㟶

齐

§

矛

妾

온. 帘兘

远

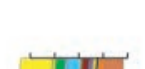

11

ई

i.

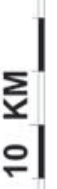

证

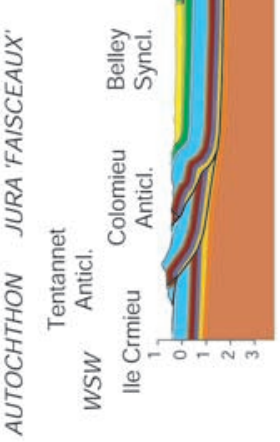

这

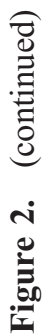

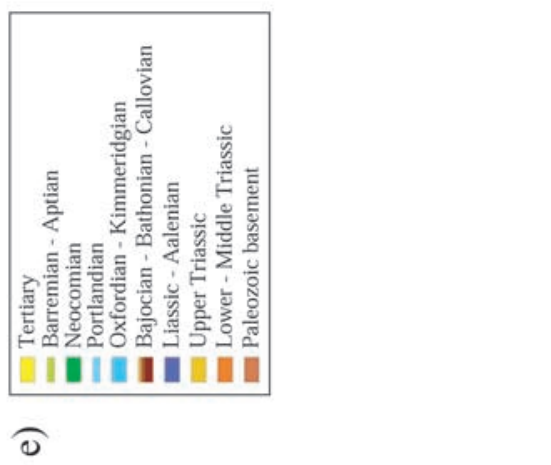




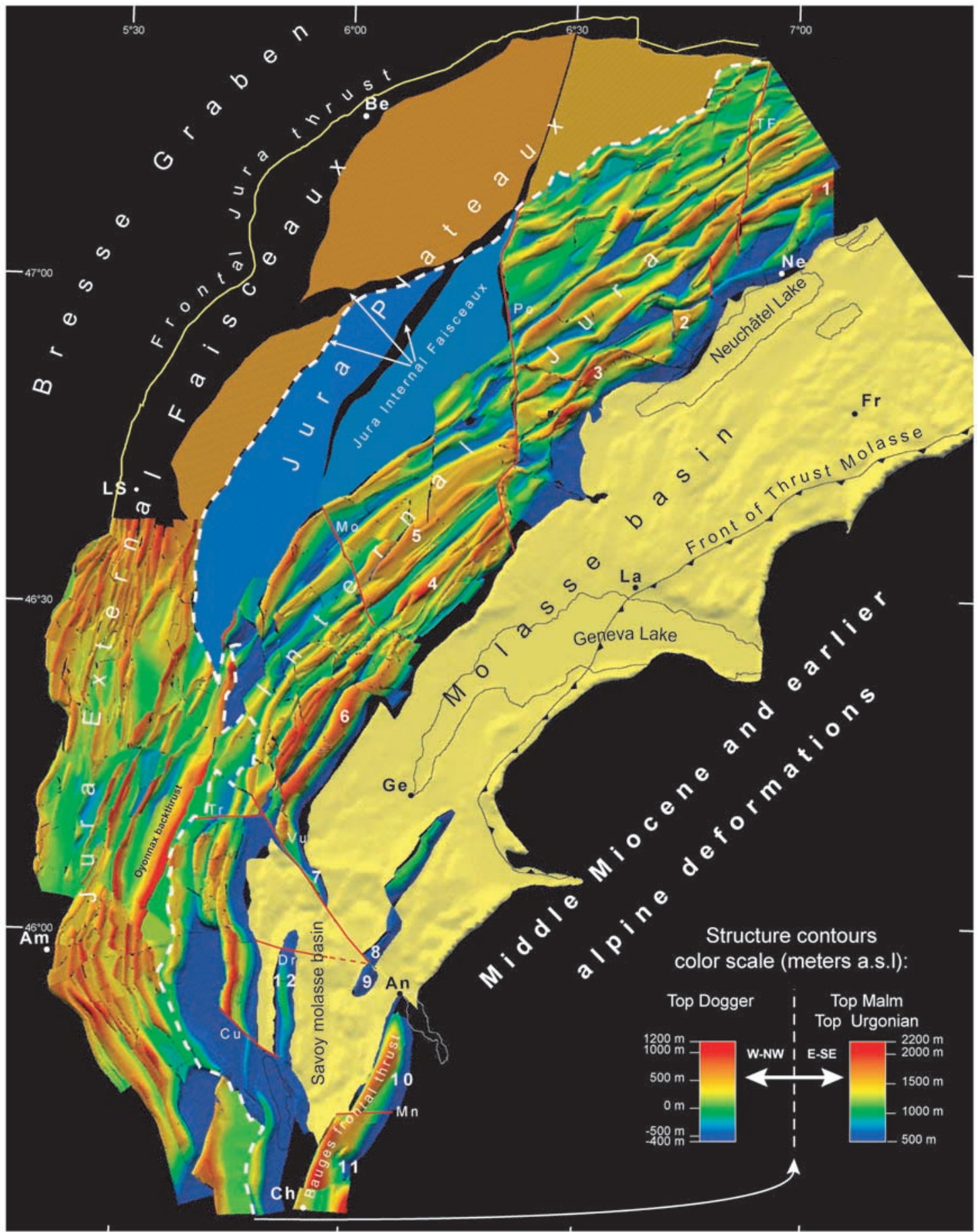

Figure 3. Map view of the 3-D model constructed for two marker horizons. Altitude of the two target surfaces are color contoured with two different scales (lower right inset). The boundary between the two surfaces is indicated by white dashed line. The 3-D model is made of 1118 individual surfaces. The gtopo30 digital elevation model from the USGS is shown in yellow for an area corresponding to the molasse basin. Legend is same as Figure 1.

were not integrated in the Jura displacement field which is younger. West of the Vuache fault it becomes more difficult to define a boundary between Jura deformations and earlier structures. As mentioned in section 2, the principal phase of thin-skinned deformation in the Jura took place from the end of the upper Miocene to the beginning of the lower
Pliocene. West of the Vuache fault, the front of the Oligocene-upper Miocene deformations (Bauges massif: Revard and Semnoz anticlines, see Figure 1 for location) was reactivated during Jura deformations and covers Serravalian sediments [Deville et al., 1994]. It is difficult to differentiate the throw associated with Jura tectonics. Moreover, the 


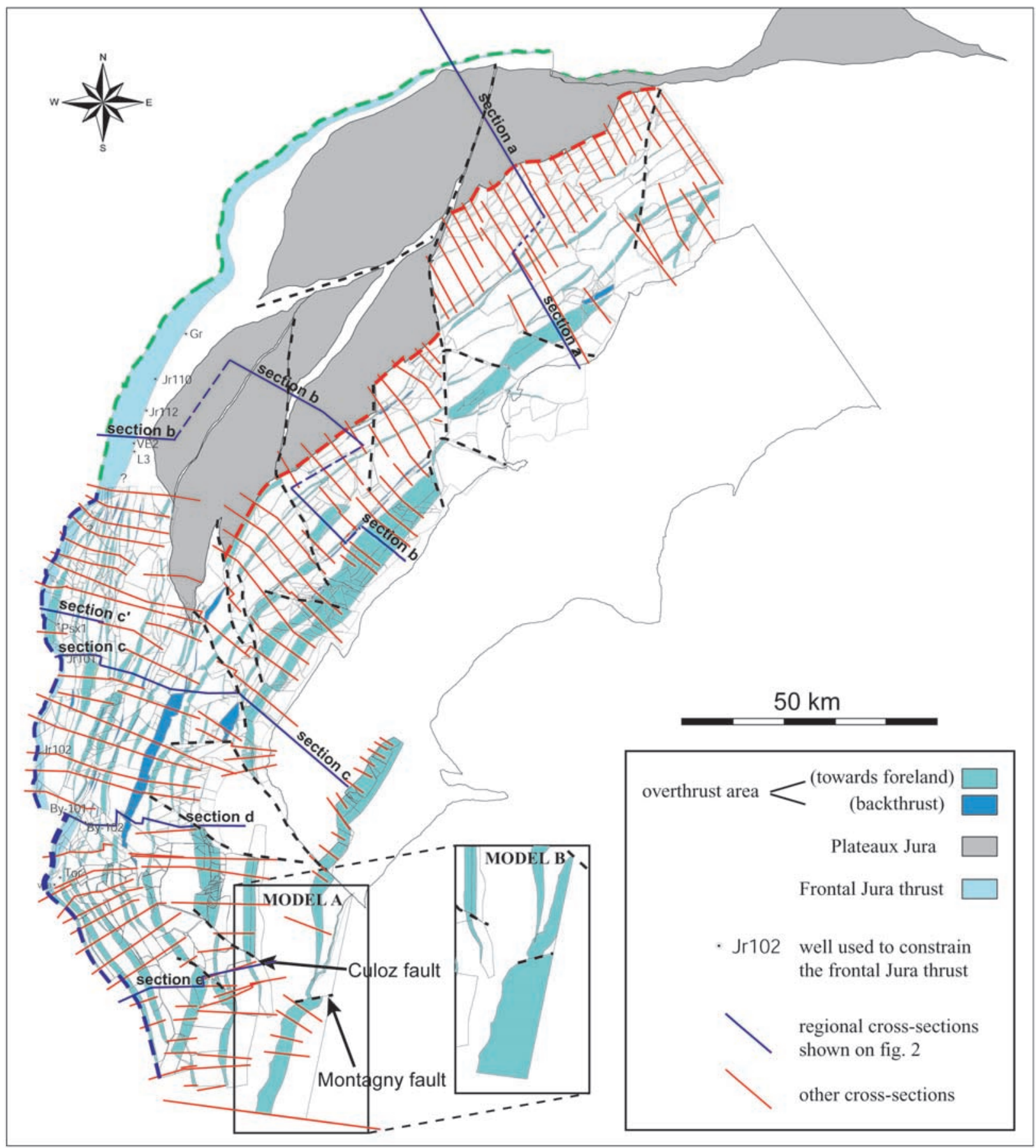

Figure 4. Plan view of the model in its deformed state. Green blue areas are overthrust zones associated with foreland-verging thrusts, dark blue areas are for backthrusts. Red lines indicate geologic cross sections drawn to build the model. Blue lines indicate location of the five transects represented on Figure 2. Black dashed lines indicate major strike-slip faults. Blue and green dashed lines indicate pin lines used for the restoration of the southern and northern parts of the model, respectively; the red dashed line represents the pin line used for the intermediate step (see text). The borehole data used to determine the limits of the Jura frontal thrust on the Bresse graben are also represented. The inset shows two alternative solutions for the overthrust of the Bauges on the Savoie molasse basin.

thrust overlap of the Bauges cover on top of the innermost Jura domain is a matter of debate. On the basis of field observations, Gidon [1988, 1990, 1996] reports that the throw at the front of the Bauges-eastern Chartreuse thrust cannot exceed 3-4 $\mathrm{km}$ at the Guiers Mort and Chéran transverse valleys (model A, see section 3.1.3). In contrast, other authors have predicted an overthrust of around $10 \mathrm{~km}$ [Deville and Chauvière, 2000; Doudoux et al., 1982; Ménard, 
a)

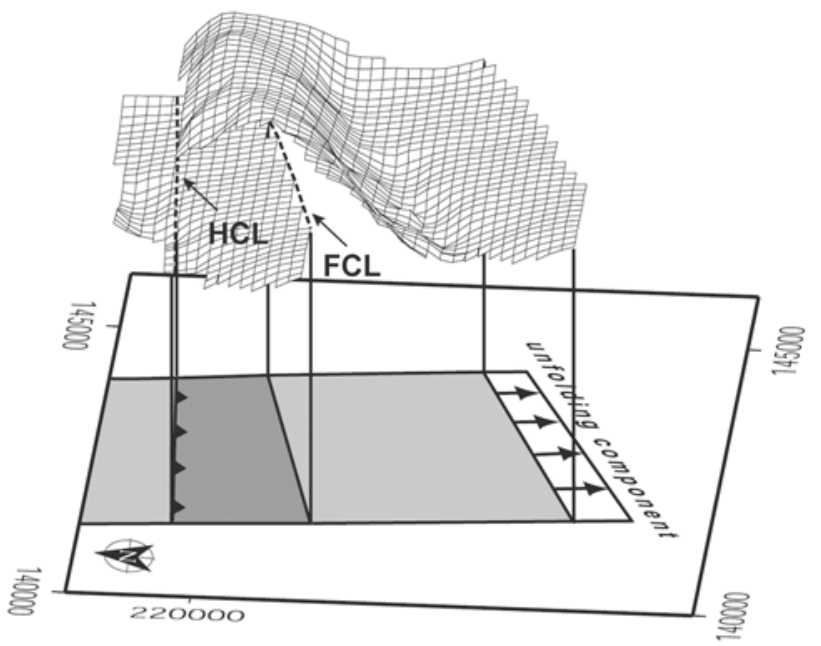

b)

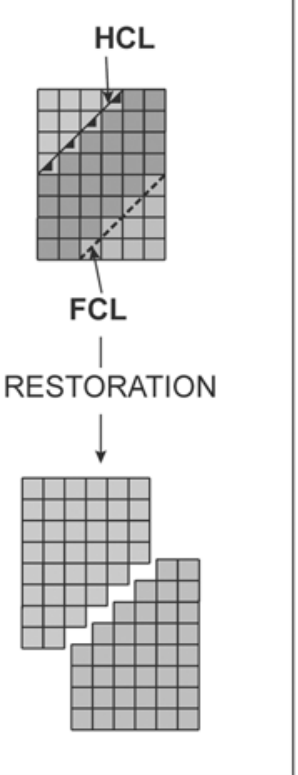

Figure 5. Illustration of the two stage restoration of folded and faulted layers using the UNFOLD software. (a) Perspective view of two gridded surfaces, the right one being thrust upon the left one. The flattening of finite elements by UNFOLD (graph below) allows to infer the direction of shortening (arrows). (b) In a second step (map view), a $20^{\circ} \mathrm{W}$ directed translation of the hanging wall gives the final restored state. The size of the gaps which remain between restored blocks depends on the size of the Cartesian grid used to interpolate surfaces. HCL, hanging wall cutoff line; FCL, footwall cutoff line.

1987], on the basis of seismic data or structural correlations (model B, Figure 4, see section 3.1.3). In our work we therefore consider both possibilities (see sections 3.1.3 and 4).

[7] For simplicity and because the outcrops do not allow the total displacement to be quantified everywhere, the 3-D model was not constructed for the whole Jura belt. The Jura "Faisceaux" part of the model was discontinued north and east of Lons-le-Saunier (Figure 1), because the Dogger limestone backbone of folds is eroded, making shortening difficult to quantify. Similarly, the narrow and highly deformed strips between the Jura Plateaux were not modeled. The shortening accommodated in these areas of the Jura Faisceaux was taken into account in our final restoration. Finally, the model (thick dashed line on Figure 1) does not cover the Internal Jura east of the Chasseral Mountain (Figure 1).

\subsubsection{Cross Section Construction}

[8] Once a consistent area of study was defined, serial cross sections were constructed using geological maps, well data and seismic line interpretations by Sommaruga [1995] and Colletta et al. [2002]. The seismic data were mainly used to localize the depth of the main detachment horizon. The regional décollement of the Jura cover takes place in Keuper evaporites which do not form a strong seismic reflector. Most seismic interpretations in the area use the top Muschelkalk as a reference horizon because it corresponds to a strong reflector above a mainly unreflective basement. The serial cross sections were drawn perpendicular to fold axes and were roughly balanced. Cross section balancing techniques are needed to determine the geometrical limits at depth where the resolution of seismic lines is low, and where well data are lacking. The resulting geometry at depth seems relatively simple compared with other fold-thrust belts. Thrusts form ramps which cut up from the basal detachment until they reach the surface or remain buried in the case of fault propagation folds. Secondary detachment levels exist in Liassic and Oxfordian marls, creating flats in these horizons. No duplex systems seem to have developed in the area of interest. Duplexes have, however, been reported in the eastern Jura [Bitterli, 1988] where the deformation style is significantly different due to changes in the nature of the deformed cover.

\subsubsection{Building of the 3-D Model}

[9] The third stage consisted in determining the 3-D structure of a marker horizon, i.e., a geological surface which can be used as a marker of deformation. Elevation of a marker horizon was plotted every $100 \mathrm{~m}$ (down to $50 \mathrm{~m}$ ) on cross sections. The corresponding points were then plotted on French and Swiss geological maps at 1:50,000 and 1:25,000 scales respectively, and curves were drawn by hand between points for a given elevation from section to section, forming structure contour curves. This hand contouring allowed the integration of lateral changes observed on geological maps between cross sections (changes in strike and dip of beds, cross-strike faults, etc). The top Urgonian ( $\sim 114 \mathrm{Ma})$, top Malm ( 135 Ma) and top Dogger ( $\sim 154 \mathrm{Ma})$ were chosen as marker horizon in the Bauges Massif, Internal Jura and Faisceaux Jura, respectively, because their outcrops are widespread in these areas. Furthermore the internal deformation of these thick limestones is negligible compared to the folding deformation. This is a prerequisite for the flexural-slip unfolding method (see section 3.2.1). A map view of the 3-D model is shown 


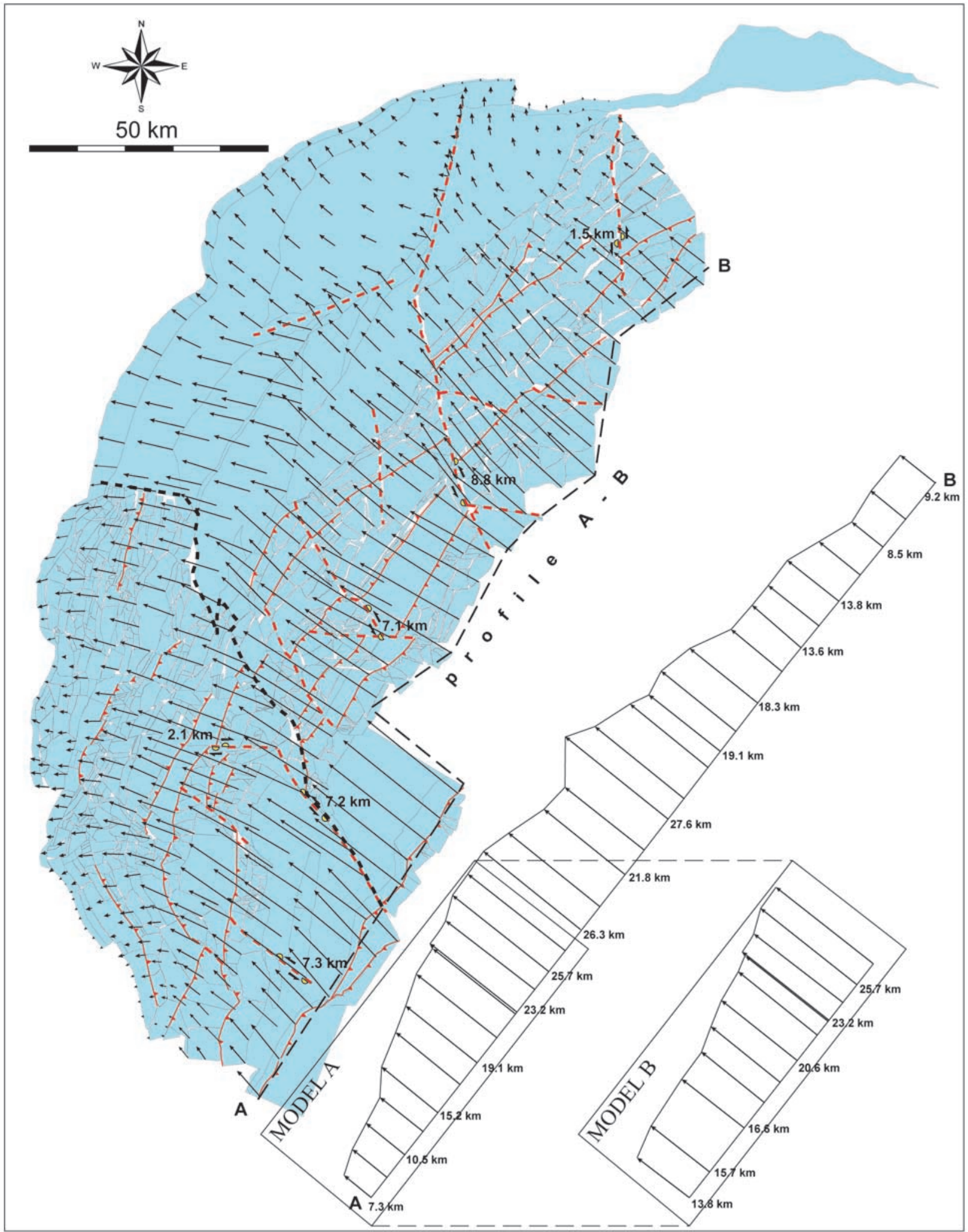

Figure 6. Undeformed state of the model and corresponding displacement field. Thick black dashed line indicates limit between the two parts of the model restored separately. Thin black dashed line indicates location of a NE-SW profile across the displacement field. The profile is different whether model A or B is considered (see Figure 4). A few thrust faults (red lines) are drawn in their restored configuration so that their strike can be compared with displacement vectors. The maximum offset across the main tear faults (red dashed lines) is also shown. Reference points across the faults are shown as yellow half circles. See text for more details. 
on Figure 3. The three marker horizons are color contoured as a function of their elevation, with two different color scales for the top Dogger and for the top Malm-top Urgonian. Maximum elevations are found in the innermost Internal Jura $(2200 \mathrm{~m})$. The overthrust zones associated with thrusts are shown as colored areas on Figure 4. Two models are presented for the southwestern part of the model where an uncertainty on the geometry of thrusts exists at depth (models A and B, see section 3.1.1).

\subsubsection{Digitizing and Interpolating Surfaces}

[10] Once the 3-D model is constructed it is divided into patches so that, at the scale of the model, individual patches can be considered as folded surfaces without significant internal shear strain. For this purpose every fault-related offset of stratigraphic contacts seen on geological maps was taken as a lateral boundary for a patch, leading to a large number of patches (1118). The faults that were integrated in the model are represented on Figure 1. Structure contour curves of individual blocks digitized and the scattered data interpolated using spline functions from the Generic Mapping Tools program [Wessel and Smith, 1995] to obtain three-dimensional gridded surfaces. The size of the grid depends on the accuracy expected from the gridding of the scattered data points. In our case the grid usually consists of elements $100 \mathrm{~m}$ square, less for small patches.

\subsection{Restoration of the 3-D Model}

\subsubsection{Unfolding of Surfaces}

[11] The UNFOLD rigid element surface-balanced program [Gratier and Guillier, 1993; Gratier et al., 1991] was used to unfold individual blocks (Figure 5). This unfolding method assumes a flexural-slip mechanism of folding (see section 1). Rigid elements are successively laid flat by UNFOLD and best fitted by a least squares method [Etchecopar, 1977]. A fitting value is calculated for each rigid element and a mean value of the fitting indicator is expressed for the whole surface. If the surface is not developable, the processing results in a distortion of the grid for low mismatches and is aborted below a given fitting value. In our case the surface of individual blocks was small and accurate enough to avoid major unfolding discrepancies. However, it should be borne in mind that no modeled flexural-slip surface is free of approximation (either due to poorly defined geometry or internal strain), and that a slight deformation of the unfolded grid is therefore always observed $(<0.5 \%)$. Moreover, these unfolding methods cannot be used to determine the location of internal deformation within individual patches, as the distortion of the grid depends on the direction of "ironing" when unfolding nondevelopable surfaces.

\subsubsection{Fitting of Blocks}

[12] Unfolded blocks were fitted manually in order to remove the component of shortening associated with thrusts. Although automatic methods for best fitting of rigid elements exist [Audibert, 1990; Rouby et al., 1993], we chose to carry out this process manually because it enabled us to follow criteria which are not integrated in automatic routines. The following criteria were used to constrain the fitting of blocks:

[13] 1. At a local scale the backward translation of blocks was guided by strike-slip faults chosen as lateral boundaries for patches. In the cases where strike-slip faults were at a high angle to thrusts, this resulted in a dip-slip translation of blocks.

[14] 2. Some thrust geometries necessitate a component of rotation. This happens if the throw of a thrust increases laterally and if this displacement gradient is not accommodated by some transport-parallel simple shear. In the Jura, cases of transpressive motions have been described by Tschanz and Sommaruga [1993] and the geometric criteria that can be used to identify this type of deformation have been presented by Wilkerson et al. [2002]. Outside from these cases of rotation, only translations were imparted to the blocks of the model.

[15] 3. We checked that the sense of movement of strikeslip faults corresponded to what was expected from other criteria (geometry relative to other strain markers, striae on fault planes, etc).

[16] 4. Initially straight regional strike-slip faults (Pontarlier, Morez, etc. (Figure 1)) had to remain rectilinear in the retrodeformed state. On Figure 6 it can be seen that during deformation these faults were transported above the décollement level without distortion of their rectilinear shape.

[17] The fitting of blocks was performed in two stages. First the deformed model was divided into two areas that were restored independently. The black dashed line on Figure 6 shows the limit between the two zones. The southwestern area was restored progressively from the Jura front (Figure 4, dark blue dashed line) toward the hinterland. For the northeastern area, a temporary local pin line was needed, given that deformations of the Jura Faisceaux were not integrated in our model because of poor definition of shortening limits in this area (see section 3.1.1). The local pin line (Figure 4, red dashed line) was set at the boundary between the Internal Jura and the Jura Plateaux which behaved as rigid blocks during deformation. An estimate of displacement associated with the Jura Faisceaux plus the displacement associated with the Jura frontal thrust (Figure 4, green dashed line) in front of the northeastern zone defined above was then added to the displacements determined for the local reference frame. The overthrusting of the Jura Mesozoic cover on the Oligocene to early Pliocene deposits of the Bresse graben can be quantified based on well data which have found Cenozoic sediments beneath the Keuper detachment level [Chauve et al., 1988b; Michel et al., 1953].

[18] The second stage of the fitting process consisted in joining the two restoration areas. This step allowed checking of the consistency of the model. The resulting restored map does not show any significant gap or overlapping of blocks between the two areas (Figure 6). The fundamental reason for this good fit is that substantial rotations are found in the southwestern restoration area so that no overlapping of patches occurs at the center of the arc. As we will see in the results section, this rotation results from a significant decrease in the shortening accommodated by the Jura toward its southwestern termination.

\subsection{Validity of Restoration and Errors on Displacements}

[19] As mentioned in section 2, the frontal Jura is thrust on top of the Bresse graben. The validity of restoring such a 


\section{unidirectional displacement model}

a)

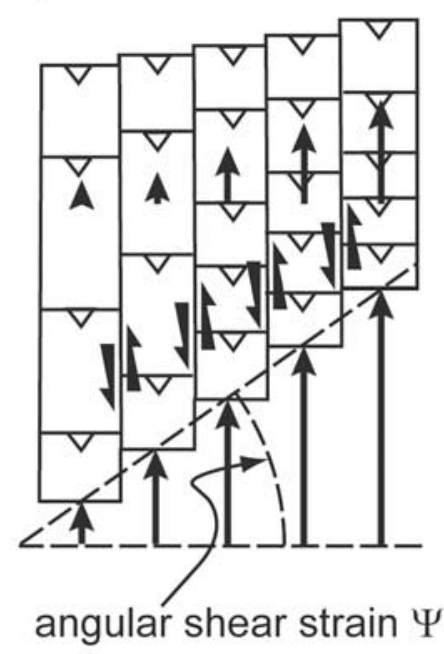

b)

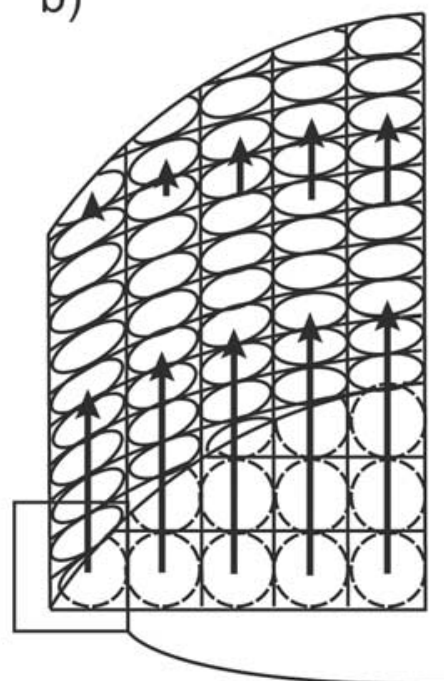

divergent displacement model

c)

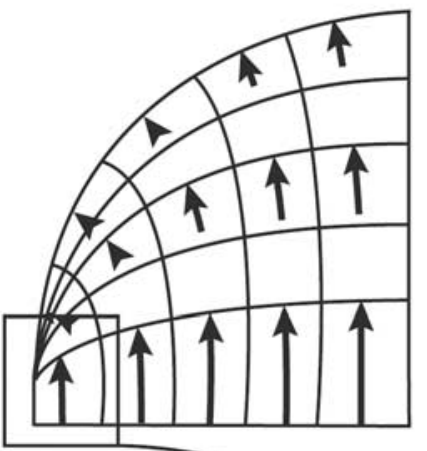

d)

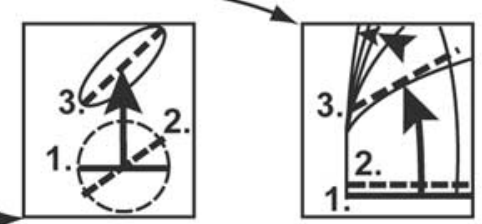

Figure 7. Two mechanisms of arcuate collisional belt formation characterized by their displacement field: unidirectional displacement model (Figures $7 \mathrm{a}$ and $7 \mathrm{~b}$ ) and divergent displacement model (Figure 7c). (a) Unidirectional displacement model with discontinuous deformation. If a displacement gradient exists perpendicular to the displacement vectors, an angular shear strain $\Psi$ exists which induces a longitudinal extension. (b) Unidirectional displacement with continuous deformation [after Hindle et al., 2002]. An angular shear strain $\Psi$ also exists in this case. (c) Divergent displacement model. (d) For models in Figures $7 \mathrm{~b}$ and $7 \mathrm{c}$, orientation of a marker line on the inner border of the arc and at three time intervals: (1) initial state, (2) after a first incremental strain, and (3) in the final deformed state.

polyphase deformation province can be questioned. Two arguments make it reasonable to try and quantify shortening in our case. First, a significant part of shortening found in the Jura Faisceaux is due to their passive transport and overthrusting on the Bresse graben. This component of shortening is documented by well data (see section 2) and is not affected by the first stage of extension. Second extension was very weak in our area of study which lay southeast of the Bresse Graben before compression set in.

[20] As far as uncertainties on results are concerned, potential errors exist on the assessment of the folding and thrusting components of shortening. An error on the folding component is minor because the geometry of folds is well documented and UNFOLD allows only the flattening of developable surfaces. In comparison the error on the translation of unfolded blocks may contribute more significantly to the final uncertainties on the displacement vectors. This error depends on two variables: the slip directions on thrust planes and unknowns on the thrusts overlaps. At a local scale, if we consider that strike-slip faulting and thrusting were coeval, slip directions on thrusts must be compatible with slip vectors on strike-slip faults. In the case of the Jura, the wide occurrence of conjugate sets of strike-slip faults provides a good constraint on local thrusting directions. Unknowns on the geometry of footwall cutoff lines of thrusts at depth contribute more significantly to the final error on displacements. Balancing criteria which are used to position foot- wall cutoff points on cross sections involve geometrical uncertainties (location of the detachment level, variations in stratigraphic thickness, etc). In the Jura, the geometrical limits of structures are well defined, which probably explains the consistency of independent restoration works. For a section where shortening is maximum, the displacements determined differ by only $6 \%$ from those obtained by Philippe [1995] and Laubscher [1965]. Finally, the internal consistency of the restored 3-D model is given by the ratio of voids and overlaps to the total surface area of the model. In our case it amounts to $2-3 \%$.

\section{Results}

[21] By comparing the position of points in the deformed and restored states, it is possible to determine the displacement field associated with deformation (Figure 6). As discussed in section 3.1.1, the present-day geometry of the frontal Bauges footwall is a matter of debate. The predicted overthrusting varies from 3 to $10 \mathrm{~km}$ for a transect near Chambéry (Figures 1 and 3), and decreases northeastward, finally dying out at the northern termination of the Semnoz anticline (Figures 1 and 3). Two models are shown on Figures 4 and 6 with differing amounts of Miocene displacement on the frontal Bauges thrust (see section 3.1.1): model A (maximum throw of $3 \mathrm{~km}$ ) and model B (maximum throw of $10 \mathrm{~km}$ ). Even for the maximum estimate of displacement on the frontal Bauges thrust, a decrease in along-strike shortening still exists in the south of the Jura 
Table 1. Paleomagnetic Data Compiled for the Study Area ${ }^{a}$

\begin{tabular}{|c|c|c|c|c|c|c|c|c|c|c|c|c|}
\hline$\underline{\text { Site }}$ & Locality & Reference & Age, Ma & $\mathrm{R} / \mathrm{N}^{\mathrm{b}}$ & $\mathrm{TDC}^{\mathrm{c}}$ & $\begin{array}{c}\mathrm{D} / \mathrm{I},{ }^{\mathrm{d}} \\
\mathrm{deg} / \mathrm{deg}\end{array}$ & $\alpha_{95}$ & $\Delta \mathrm{D},{ }^{\mathrm{e}} \operatorname{deg}$ & $\begin{array}{c}\text { Reference } \\
\text { Paleopole } \\
\text { Latitude/ } \\
\text { Longitude }^{\mathrm{f}}\end{array}$ & $\begin{array}{c}\text { Reference } \\
\text { Declination, }{ }^{\mathrm{g}} \\
\text { deg }\end{array}$ & $\begin{array}{c}\text { Rotation, }{ }^{\mathrm{h}} \\
\text { deg }\end{array}$ & $\begin{array}{r}\Delta \mathrm{R}^{\mathrm{i}}{ }^{\mathrm{N}} \\
\mathrm{deg}\end{array}$ \\
\hline 1 & Mandach & Gehring et al. [1991] & $161-157$ & $0 / 18$ & yes & $23.7 / 65.7$ & 1.8 & 4.3 & $75 / 147$ & -10 & 13.7 & \pm 3.5 \\
\hline 2 & Herznach & Gehring et al. [1991] & $161-157$ & $2 / 29$ & yes & $-1 / 50.2$ & 3.7 & 5. & $75 / 147$ & -10 & -11 & \pm 4.6 \\
\hline 3 & Unterehrendingen & Gehring et al. [1991] & $161-157$ & $0 / 19$ & yes & $2.7 / 48.9$ & 6 & 9.1 & $75 / 147$ & -10 & -7.3 & \pm 7.3 \\
\hline 4 & Holderbank & Gehring et al. [1991] & $161-157$ & $0 / 15$ & yes & $14.1 / 52.1$ & 5.5 & 8.9 & $75 / 147$ & -10 & 4.1 & \pm 7.2 \\
\hline 5 & Wildegg & Gehring et al. [1991] & $161-157$ & $0 / 13$ & yes & $24 / 61.1$ & 3.4 & 7.0 & $75 / 147$ & -10 & 14 & \pm 5.6 \\
\hline 6 & Gatter & Gehring et al. [1991] & $161-157$ & $3 / 10$ & yes & $16.6 / 57.4$ & 6.6 & 12.3 & $75 / 147$ & -10 & 6.6 & \pm 9.9 \\
\hline 7 & Schellenbrücke & Gehring et al. [1991] & $161-157$ & $0 / 5$ & yes & $14.5 / 62.9$ & 11.5 & 25.9 & $75 / 147$ & -10 & 4.5 & \pm 20.8 \\
\hline 8 & Liesberg & Gehring et al. [1991] & $161-157$ & $0 / 26$ & yes & $20 / 44.6$ & 4.6 & 6.4 & 147 & -10 & 10 & \pm 5.2 \\
\hline 9 & Reuchenette & Gehring et al. [1991] & $161-157$ & $5 / 55$ & yes & $11.2 / 59.1$ & 2.3 & 4.4 & $75 / 147$ & -10 & 1.2 & \pm 3.6 \\
\hline 10 & S.Sulpice & Gehring et al. [1991] & $161-157$ & $0 / 14$ & yes & $36.1 / 61.7$ & 5.2 & 11.0 & $75 / 147$ & -10 & 26.1 & \pm 8.8 \\
\hline 11 & Baumes & Gehring et al. [1991] & $161-157$ & $0 / 4$ & yes & $24.3 / 62.6$ & 10.9 & 24.2 & $75 / 147$ & -10 & 14.3 & \pm 19.4 \\
\hline 12 & S.Claude & Gehring et al. [1991] & $161-157$ & $6 / 6$ & yes & $3.9 / 63.7$ & 5 & 11.3 & 47 & -10 & -6.1 & \pm 9.1 \\
\hline 13 & Selignac & Gehring et al. [1991] & $161-157$ & $0 / 12$ & yes & $-6.8 / 45.1$ & 6.9 & 9.7 & $75 / 147$ & -10 & -16.8 & \pm 7.8 \\
\hline 14 & Arvière & Gehring et al. [1991] & $161-157$ & $11 / 0$ & yes & $5.8 /-53.4$ & 4.6 & 7.7 & $75 / 147$ & -10 & -4.2 & \pm 6.2 \\
\hline 15 & Lucey & Gehring et al. [1991] & $161-157$ & $0 / 25$ & yes & $18.5 / 46.8$ & 2.2 & 3.2 & $75 / 147$ & -10 & 8.5 & \pm 2.6 \\
\hline 16 & Findreuse & Burbank et al. [1992] & $26-21$ & $55 / 39$ & no & $-7.8 / 53.75$ & 6.3 & 10.6 & $78 / 155$ & -6 & -13.8 & \pm 8.6 \\
\hline 17 & Fornant & Burbank et al. [1992] & $26-21$ & $55 / 39$ & no & $-7.8 / 53.75$ & 6.3 & 10.6 & $78 / 156$ & - & -13.8 & \pm 8.6 \\
\hline 18 & Fischenbach & Kempf et al. [1998] & $23-21$ & $231 / 87$ & no & $23 / 35$ & 4.2 & 5.1 & $78 / 157$ & -6 & 17 & \pm 4.1 \\
\hline 19 & Honegg & Kempf et al. [1998] & $29-25$ & $60 / 72$ & no & $22 / 54$ & 4.9 & 8.3 & $78 / 158$ & -6 & 16 & \pm 6.7 \\
\hline 20 & Mt.Vully & Kempf et al. [1998] & $21-20$ & $32 / 36$ & no & $19.85 / 44.2$ & 11.95 & 16.7 & & - & 13.8 & \pm 13.4 \\
\hline 21 & Napf & Kempf et al. [1998] & $19-14$ & $36 / 84$ & no & $15.5 / 44$ & 6.1 & 8.4 & $78 / 160$ & - & 9.5 & \pm 6.8 \\
\hline 22 & Praesserebach & Kempf et al. [1998] & $27-24$ & $63 / 72$ & no & $14 / 55$ & 4.85 & 8. & $78 / 161$ & - & 8 & \pm 6.8 \\
\hline 23 & Sense & Kempf et al. [1998] & $20-17$ & $86 / 141$ & no & $20.5 / 47.45$ & 5.25 & 7.7 & $78 / 162$ & -6 & 14.5 & \pm 6.2 \\
\hline 24 & Talent & Kempf et al. [1998] & $29-23$ & 203/219 & no & $18 / 46.6$ & 3.8 & 5.5 & $78 / 163$ & -6 & 12 & \pm 4.4 \\
\hline 25 & Zürich & Kempf et al. [1998] & $15-13$ & $21 / 111$ & no & $17.35 / 46.25$ & 6.85 & 9.9 & $78 / 164$ & -6 & 11.3 & \pm 7.9 \\
\hline
\end{tabular}

${ }^{\mathrm{a}}$ For location map of sites, see Figure 8

${ }^{\mathrm{b}}$ Number of samples with reversed $(\mathrm{R})$ and normal $(\mathrm{N})$ polarity.

${ }^{\mathrm{c}}$ In the Jura fold-thrust belt, tectonic dip correction (TDC) applied by Gehring et al. [1991]. In the essentially flat-lying molasse basin TDC is not necessary.

${ }^{\mathrm{d}}$ Mean declination/inclination.

${ }^{\mathrm{e}}$ Error uncertainty calculated using $\Delta \mathrm{D}=\sin ^{-1}\left(\sin \left(\alpha_{95}\right) / \cos (\mathrm{I})\right)$ [Demarest, 1983; Butler, 1992].

${ }^{\mathrm{f}}$ Reference mean paleopole drawn from Kadzialko-Hofmokl and Kruczyk [1987] and Besse and Courtillot [1991].

${ }^{g}$ Reference declination for the study area based on the reference paleopole.

${ }^{\mathrm{h}}$ Vertical axis rotation equal mean delcination minus reference declination; positive rotations, clockwise; negative rotations, counterclockwise.

${ }^{\mathrm{i}}$ Error uncertainty $\Delta \mathrm{R}=0.8 \Delta \mathrm{D}$ [Demarest, 1983; Butler, 1992].

arc. On Figure 6, displacement vectors along the trailing pin line were projected onto a NE-SW straight line in order to show the cumulative effect of upper Miocene to lower Pliocene deformations at the front of the Alps. The most striking features of the displacement field shown on Figure 6 are as follows:

[22] 1. In the internal zones the displacement field is essentially parallel and oriented SE-NW. Displacement increases progressively from $9 \mathrm{~km}$ in the northeastern corner of the model to $28 \mathrm{~km}$ at the rear of the Mount Tendre/Risoux thrusts. It stays above $23 \mathrm{~km}$ up to the Vuache fault and then decreases progressively to $7 \mathrm{~km}$ (case A) or $14 \mathrm{~km}$ (case B). In the Jura hinterland, this lateral decrease in displacement must produce a deformation which can be accommodated either by a rotation or by a shear strain. On this basis, it appears that the molasse basin must have been rotated $\sim 10^{\circ}$ clockwise around a vertical axis east of the Vuache fault. This value is very close to the one obtained by Laubscher [1961], who determined a rotation of $7^{\circ}$. Similarly, our results predict that the Savoie molasse basin west of the Vuache fault must have undergone a counterclockwise rotation. For model A, this displacement gradient corresponds to a $18^{\circ}$ vertical axis rotation of the Savoie molasse basin. In model B, which minimizes the displacement gradient in the southern Jura, the rotation is $12^{\circ}$. If it is assumed that the $18^{\circ}$ rotation of the Savoie molasse basin was accommodated by an angular shear strain $\Psi$ (Figure $7 \mathrm{a}$ ) rather than a rigid body rotation, the corresponding longitudinal extension $e$ can be calculated [e.g., Ramsay and Huber, 1983]:

$$
\begin{aligned}
e & =\left(1-2 \gamma \cos \alpha \sin \alpha+\gamma^{2} \sin ^{2} \alpha\right)^{1 / 2}-1 \\
& =\left(1+(\tan 18)^{2}\right)^{1 / 2}-1 \\
& =0.05=5 \%
\end{aligned}
$$

for $\alpha=90^{\circ}$ (reference line at right angles to displacement vectors) and $\gamma$ is shear strain $\tan \Psi$.

[23] 2. Displacement vectors become perpendicular to the outer arcuate rim of the Jura. The change in vector direction is generally progressive, except where strain partitioning occurs across strike-slip faults. In the southern Jura, where the main change in fold axis direction occurs, a substantial anticlockwise rotation (a maximum of $30^{\circ}$ for the inner folds) is predicted. This is more than the $18^{\circ}$ of rotation observed for the trailing reference line, because $12^{\circ}$ of rotation are accommodated by the Bauges frontal thrust in between. Furthermore, although displacement vectors are generally nearly perpendicular to thrusts in the deformed state, they deviate by as much as $30^{\circ}$ 


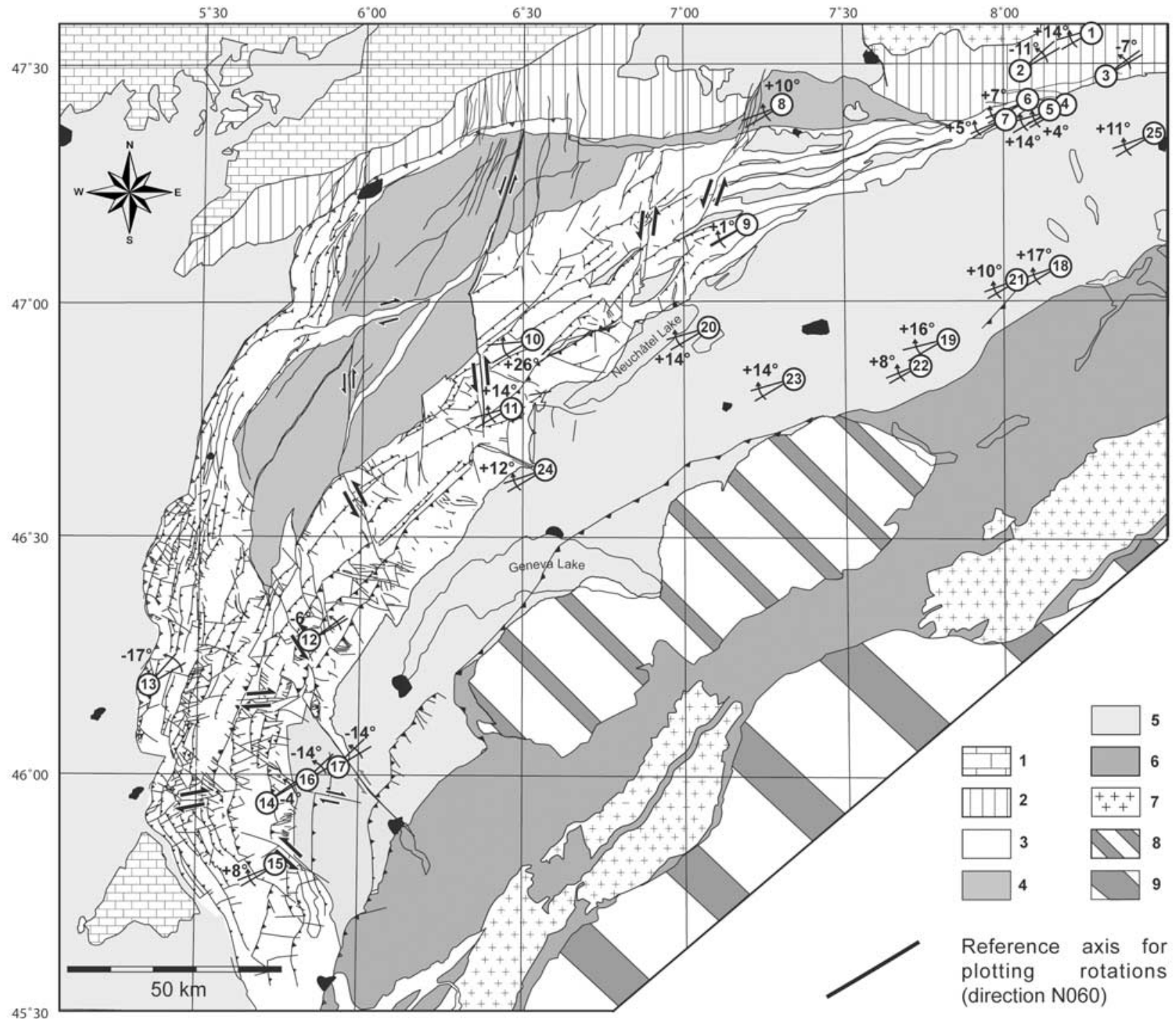

Figure 8. Vertical axis rotations according to paleomagnetic data of Table 1. Numbers in circles are sites referred to in Table 1. Clockwise rotations are positive; counterclockwise are negative. For legend, see Figure 1.

from a perpendicular to the innermost fold axes of the southern Jura.

[24] 3. The left-lateral offset across the southeastern end of the Vuache fault is less than $2 \mathrm{~km}$. This confirms that the Mandallaz and Montagne d'Age anticlines (Figures 1 and 3) form a single structure. The offset increases to $7.2 \mathrm{~km}$ north of the Mont Vuache where the "Crêt de la Neige" anticline (Figures 1 and 3) branches on the Vuache fault. This $5.2 \mathrm{~km}$ increase in offset is due to the Droisy right-lateral strike-slip fault (Figures 1 and 3) which transfers displacement from the "Gros-Foug" anticline (Figures 1 and 3) to the Vuache fault. This shows that the Vuache fault is relaying displacement between thrusts in its northeastern and southwestern blocks. The same is true for the other major strike-slip faults of the Jura such as the Pontarlier fault which has a maximum $9 \mathrm{~km}$ left-lateral offset.

[25] 4. Some displacement vectors seem to originate and diverge from a single point. This is where strike-slip displacement occurs across a fault. This local and relative movement is combined with the cumulative displacement in front of the strike-slip fault to form the total displacement field at this point.

\section{Discussion}

\subsection{Models of Arc Formation}

[26] In the past, genetic and descriptive classifications of arcuate fold-thrust belts have been proposed [Argand, 1924; Hindle and Burkhard, 1999; Carey, 1955; Ferrill and Groshong, 1993; Macedo and Marshak, 1999; Marshak, 1988; Ries and Shackleton, 1976]. Because a displacement field wholly describes the relative motion of points during the arc formation, it is very appropriate to classify arcs. A displacement field is characterized by three features: (1) its divergence, (2) the displacement gradient parallel to transport directions, and (3) the lateral gradient of displacement. Existing models of arc formation can be opposed on the divergence of the displacement vectors (Figure 7): 


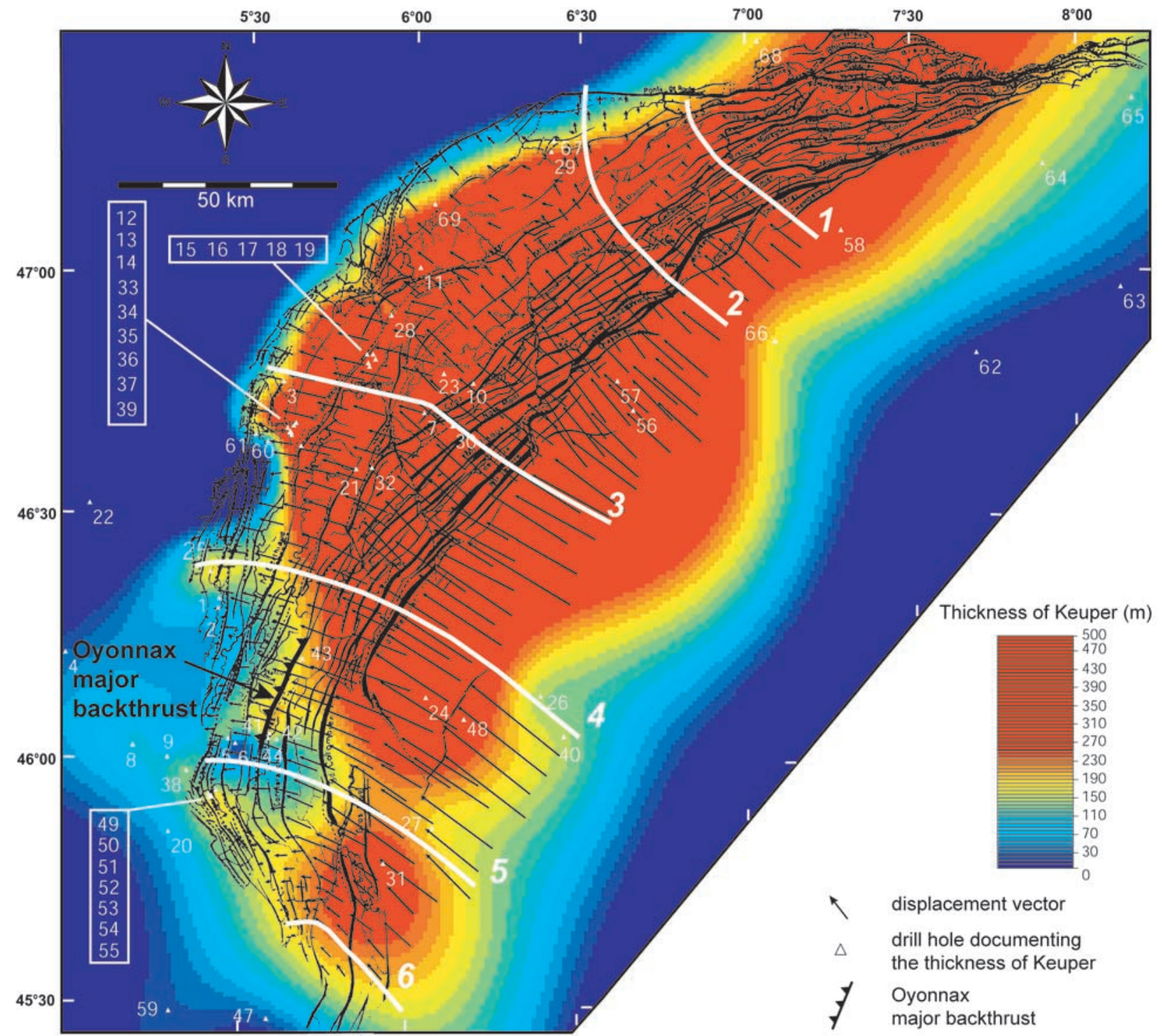

Figure 9. Distribution map of Keuper evaporites, major fold axes [Heim, 1921], and displacement field of the Jura. The boreholes used for interpolating thicknesses are shown by white triangles. The six transects of Figure 10 are represented by thick white lines. Wells: 1, Jura101; 2, Jura103; 3, Jura104; 4, Bresse103; 5, Bugey101; 6, Bugey102; 7, Toillon1; 8, Bresse Sud1; 9, Bresse Sud2; 10, Laveron1; 11, Eternoz1; 12, Publy101; 13, Crancot101; 14, Crancot2; 15, Valempoulières1; 16, Valempoulières2; 17, Valempoulières3; 18, Valempoulières 101; 19, Valempoulières102; 20, Blyes101; 21, Saugeot1; 22, Ratenelle101; 23, Essertines101; 24, Humilly2; 25, Poisoux1; 26, Faucigny1; 27, Chapéry1; 28, Thesy1; 29, Orsans1; 30, Charmont1; 31, La Tailla1; 32, Bonlieu1; 33, Briod101; 34, Briod102; 35, Briod103; 36, Briod104; 37, Briod105; 38, Cormoz1; 39, Perrigny 101; 40, Brizon1; 41, Chaleyriat1; 42, La Chandelière1; 43, Chatillon1-D; 44, Chatelblanc1; 45, Saint-Lattier1; 46, Saint-Lattier2; 47, Paladru1; 48, Salève2; 49, Torcieu1; 50, Vaux-en-Bugey-Les Taches; 51, Vaux-en-Bugey1; 52, Vaux-en-Bugey2; 53, Vaux-en-Bugey3; 54, Vaux-en-Bugey4; 55, Vaux-en-Bugey5; 56, Essavilly; 57, Treycovagnes; 58, Hermringen; 59, Bizonnes1; 60, Macornay101; 61, Messia1; 62, Linden; 63, Entlebuch; 64, Pfaffnau; 65, Shaffisheim; 66, Courtion; 67, Buez; 68, Buix; 69, Montrond-le-Château.

[27] In a unidirectional displacement model (Figures $7 \mathrm{a}$ and $7 \mathrm{~b}$ ), the transport direction remains parallel during the progressive formation of the arcuate structure. In the case where shortening is accommodated by discontinuous deformations (Figure 7a), the limbs of the arc correspond to wrenching zones. If shortening is accommodated by continuous deformations (Figure 7b), strain markers (folds) develop oblique to the displacement direction from the onset of deformation (Figure 7d, left) [Hindle and Burkhard, 1999] and angles between strain markers and displacement increase during the progressive development of the arcuate structure. The fact that the long axis of 


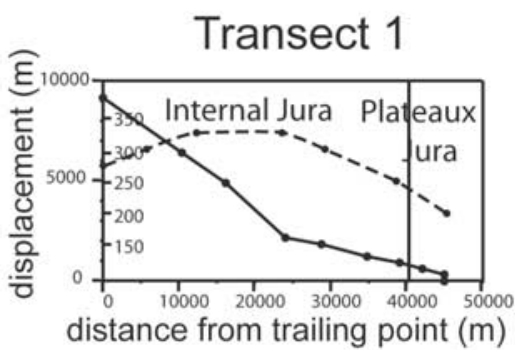

Transect 2

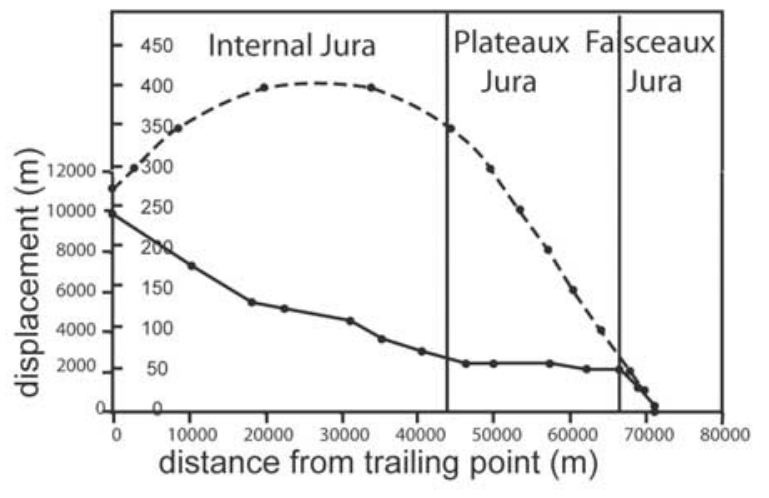

Transect 3

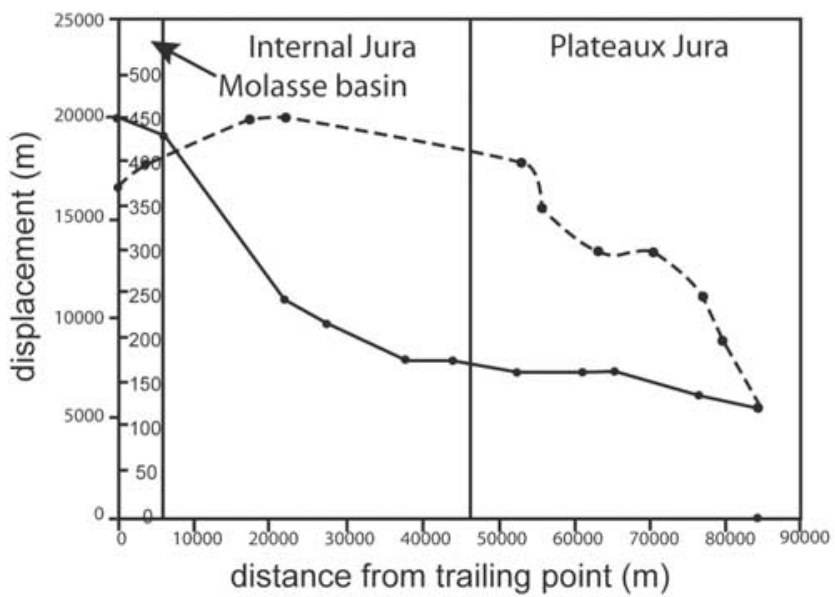

Transect 4

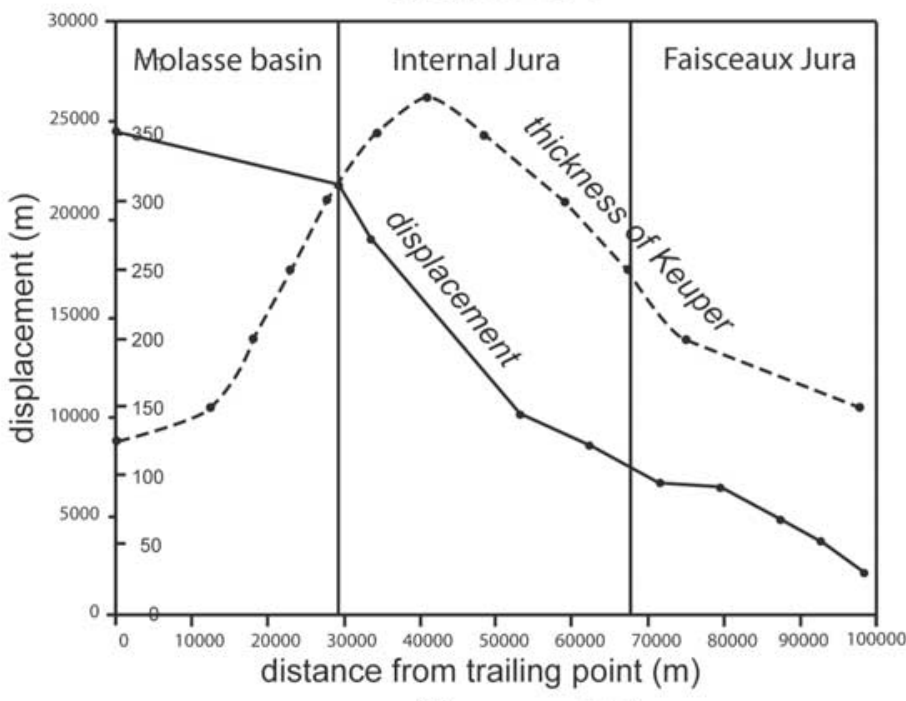

Transect 5

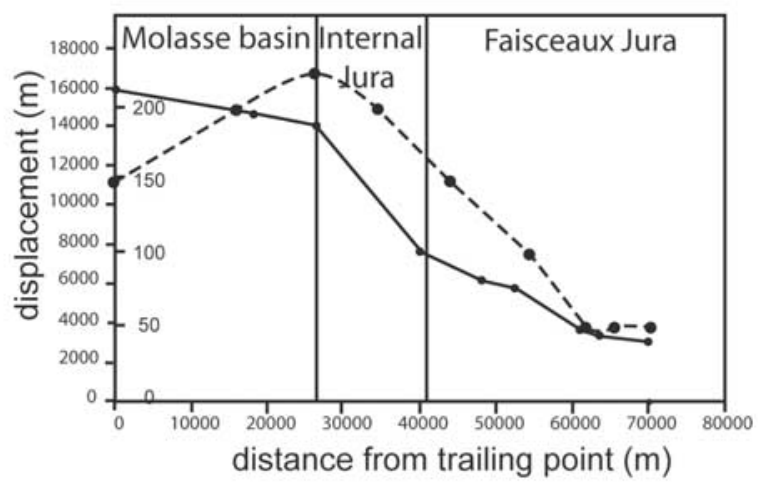

Figure 10. Diagrams of displacement versus distance from a trailing reference point for six transects across the Jura displacement field (solid lines). For each transect, the thickness variation of the main detachment level (Keuper) is also shown (dashed lines, inner scale (meters)). Transects are located on Figure 9. See text for comments.

strain is at $45^{\circ}$ to displacement for the first incremental shear strain (Figure 7d, left) is specific to this model and can be used to recognize it (see section 5.3). In a unidirectional displacement model, longitudinal extension is accom- modated by transport-parallel strike-slip faults (Figure 7a) or by a distributed longitudinal strain (Figure $7 b$ ). In a continuous unidirectional displacement model (Figure 7b), stress directions are fan-shaped. For the discontinuous type 
of model, the stress field is very complex and depends on the location of faults.

[28] In a divergent displacement model (Figure 7c), fold axes and thrusts remain perpendicular to the displacement direction. Passive vertical axis rotation of initially straight marker lines is related to the divergence of the displacement field (Figure 7d, right). Along the strike of folds and thrusts, longitudinal strain also accommodates the divergence in displacement. In this model, the stress field is radial.

[29] In conclusion, both unidirectional and divergent models imply radial stress trajectories, arc-parallel extensions and vertical axis rotations (except the discontinuous unidirectional model). Therefore, if the displacement field is not known, it seems hazardous to use one of these parameters to determine parallel or divergent displacements a priori. Although the use of rigid body rotations is not decisive to discriminate between models of Figures $7 \mathrm{~b}$ and $7 \mathrm{c}$, they can be used to back up or discard model of Figure $7 \mathrm{a}$. In the following, before comparing the Jura displacement field with the above models, existing data on vertical axis rotations in the Jura are presented.

\subsection{Paleomagnetic Data in the Jura}

[30] It is assumed that the patches making up the 3-D model behaved as rigid blocks with negligible internal strain, and provided that the individual structures associated with rotation can be recognized, a restoration can theoretically allow the prediction of vertical axis rigid rotations. Existing paleomagnetic data for the Jura Mountains and the molasse basin are listed in Table 1 and the calculated rotations are shown on Figure 8. Three sources of data are available for this area: declination/inclination values gathered from Middle Jurassic limestones [Gehring et al., 1991], from the Lower Freshwater Molasse [Burbank et al., 1992] and from molasse rocks in general [Kempf et al., 1998]. Rotations shown on Figure 8 are mean values between normal and reversed polarities. Furthermore, paleomagnetic studies provide only relative values of rotations. Absolute rotations depend on the position of the Earth's magnetic pole when rocks were deposited. In our case, the paleopole of Besse and Courtillot [1991] was used for the molasse deposits, which were laid down during Oligocene and Miocene times. The paleopole for Eurasia published by these authors has geographic coordinates of $78^{\circ} / 155^{\circ}$ (latitude/longitude) which corresponds to a declination of $6^{\circ}$ east of the present-day geographic north for our area of interest. The mean paleopole determined by Besse and Courtillot [1991] for a period ranging from 10 to $30 \mathrm{Ma}$ is based on four poles determined independently, with a $\alpha_{95}$ of 8 . For Middle Jurassic samples, a declination value of $10^{\circ}$ east of the present-day geographic north was used, based on a compilation of data for stable Europe by Kadzialko-Hofmokl and Kruczyk [1987]. The paleopole determined by Kadzialko-Hofmokl and Kruczyk is 75/147 (latitude/longitude) and is based on 12 data values, with a $\alpha_{95}$ of 5 . Vertical axis rotations have been calculated with respect to the above mentioned paleopoles (see Table 1) and have been plotted relative to an arbitrary N060 direction on Figure 8 , to highlight a possible symmetry between clockwise and anticlockwise rotations. Although all sites published by Burbank et al. [1992], Gehring et al. [1991], and Kempf et al. [1998] have been plotted on Figure 8, sites with a low number of samples show high uncertainties $(\Delta R$, see Table 1) and therefore should not be taken into account.

[31] Rotations found using the above mentioned declination values show that two consistent areas of rotation can be recognized. The data from Kempf et al. [1998] show a $8^{\circ}$ to $14^{\circ}$ clockwise rotation of the molasse basin east of the Vuache fault. In contrast, data from Burbank et al. [1992] show an anticlockwise rotation of $14^{\circ}$ west of this fault. Data drawn from Gehring et al. [1991] match this geometry with both clockwise and anticlockwise rotations up to around $20^{\circ}$ in the eastern and western parts respectively. In conclusion, even though a consistent pattern of rigid body rotations exists in the Jura, rotations appear to be much less than the $90^{\circ}$ change in strike around the arc.

\subsection{Previous Models for Jura Formation}

[32] Prior to our study, two attempts had been made to reconstruct or model the Jura displacement field at the scale of the whole arc. First, Philippe [1995] used a pseudo-three-dimensional block mosaic method (see section 1) attributing shortening values deduced from nonparallel balanced cross sections to individual patches. The fitting of blocks was then performed separately for two areas delimited by the Vuache fault, and these two domains were put together in a second step, as in our restoration. However, in the case of Philippe [1995], as restoration was done along radial cross sections, this resulted in a significant overlapping of the two areas at their common border, which compelled the author to rearrange the blocks in an arbitrary way. Our work was not faced with this problem, because the method was three-dimensional, whereas the work of Philippe [1995] was a map view restoration based on cross section restoration.

[33] The second model was proposed by Hindle et al. [2000], who used an a priori unidirectional displacement field to mathematically derive the arcuate strain pattern of the Jura. This approach assumes that continuous medium mechanics can be used to infer strains from a displacement field (continuous deformations model, Figure 7b). It seems quite obvious that continuum mechanics do not apply to deformed materials where more than $80 \%$ of shortening is taken up by discontinuous deformations (strike-slip and reverse faults) as is the case in the Jura. Furthermore, the model of Hindle et al. [2000] implies a longitudinal extension of $50 \%$ for the innermost southern Jura folds, if we consider the angular shear strain $\Psi$ associated with their model. This is in contradiction with our displacement field which shows a very limited lateral extension in the southern Jura bend (5\% for internal folds and the Savoie molasse basin, see section 4). A tangential extension of $50 \%$ is clearly not seen in the field. The large longitudinal extension predicted by the model of Hindle et al. [2000] is due to a strong lateral displacement gradient, whereas the transport direction that their model forecasts is very similar to our results in the innermost southern Jura.

[34] It could be objected that the southern Jura bend corresponds to a major wrench zone, as exemplified on Figure 7a. However, this does not match field observations. Fault-striae pairs measured by Philippe [1994] in this area all show reverse faults dipping toward the E-NE and dip-slip striae, in contradiction with transpressive 
motions. Apart from this set of reverse faults, Philippe's data include conjugate strike-slip faults with horizontal striae, showing that deformation was coaxial in this area. For these reasons, striae measured on thrusts by Philippe [1994] should be considered as representative of displacements on master faults and not as instantaneous measures of a noncoaxial stress as suggested by Hindle et al. [2000]. One must say however that in the particular case of the innermost southern Jura, our retrodeformation shows a $30^{\circ}$ obliquity of folds relative to displacement in the restored state (see section 4), supporting the Hindle et al. [2000] unidirectional displacement model in the innermost southern Jura. In conclusion, it appears that whereas the Jura displacement field is clearly divergent toward the deformation front (Figure 7c), the innermost southern Jura bend results from both a passive rotation related to divergence (Figure 7c) and from an initial obliquity in a shear strain (Figure 7b).

\subsection{Present-Day Deformation in Jura and Other Arcuate Belts}

[35] A 5-year observation period of the GPS "ALPES" network has shown that velocity vectors in the Jura are generally less than $2 \mathrm{~mm} \mathrm{yr}^{-1}$ relative to the NNR-NUVEL1A Eurasian plate [Vigny et al., 2002]. Such small numbers lie at the limit of the confidence level of data and therefore cannot be used. It should be noticed that the thin-skinned deformation of the Jura between $15 \mathrm{Ma}$ and $6 \pm 3 \mathrm{Ma}$ [Affolter, 2003; Becker, 2000] involved a maximum displacement rate of only $3 \mathrm{~mm} \mathrm{yr}^{-1}$ of the Alpine hinterland relative to a fixed foreland. A striking feature of present-day deformation in the Jura is that the stress regime documented by fault plane solutions of earthquakes [Deichmann, 1992; Pavoni, 1977; Sambeth and Pavoni, 1988; Thouvenot et al., 1998] and in situ stress measurements [Becker, 2000] show a stress regime and fanning stress directions very similar to the Miocene stress field revealed by paleostress studies [Philippe, 1995] (for a different opinion, see Becker [2000]). Shortening is still going on and focal mechanisms record essentially strike-slip faulting and scarce thrusting. A major difference with the deformation style expected for Miocene to lower Pliocene thin-skinned deformation is that microearthquakes are essentially located in the crystalline basement between 5 and $15 \mathrm{~km}$ depth and even $30 \mathrm{~km}$ [Deichmann, 1992]. However, earthquakes also take place in the sedimentary cover above the Triassic décollement horizon. The $M_{L} 5.3$ Epagny earthquake of 1996 was located at the cover-basement interface $(-3 \mathrm{~km}$ below sea level) on the Vuache left-lateral strike-slip fault [Thouvenot et al., 1998]. This earthquake is one of the most important historical seismic event in the area. Its focal mechanism is consistent with the left-lateral displacement along a $\mathrm{N} 40^{\circ} \mathrm{W}$ striking fault deduced from our restoration. Because large earthquakes occur in the sedimentary cover and because seismic deformation should be analyzed in terms of earthquake moment release, the higher frequency of microseisms in the basement should not be taken as evidence that thickskinned deformation prevails and that the thin-skinned deformation of the Jura has come to an end.

[36] In other arcuate compressional settings, recent GPS data indicate fan-shaped displacements toward the arcuate front of deformation. For instance, the western foothills of the fold-thrust belt of Taiwan are composed of two arcs separated by a reentrant which corresponds to the Peikang basement high [Brusset et al., 1999]. GPS data show that present-day displacements are unidirectional at the rear of the Taiwan orogen and are progressively deflected toward the deformation front, on both sides of the basement high [Hu et al., 2001]. Other examples of divergent displacement fields have been described in the curved sub-Andean zone of Bolivia [Lamb, 2000] and in the Hellenic arcuate accretionary prism [McClusky et al., 2000]. In this latter case, it has been suggested that the driving mechanism of displacements is gravity spreading [Martinod et al., 2000].

\subsection{Gradient and Divergence of Displacements: Determining Factors}

[37] It is now generally recognized that the formation of the Jura arc is related to the distribution of the Triassic evaporites which form the detachment level of the overlying deformed sedimentary cover. The isopach map of Figure 9 shows the gross distribution of evaporites known from well data. This map shows the regional variation of salt layers and does not take into account cases of local tectonic thickening related to salt pillows. On Figure 9, the color scale was chosen in order to highlight the existence of two subbasins separated by a zone of thinner deposits. As shown by the directions of fold axes, this area corresponds to the major change in strike of the belt. Also noteworthy is the occurrence of a large backthrust, the Oyonnax anticline (for location, see Figures 1, 3, and 9 and cross sections $2 \mathrm{c}$ and $2 \mathrm{~d}$ ), precisely where the area of thinner evaporites is observed. Because of the relation between the thickness of a detachment horizon and the friction coefficient, this area is likely to coincide with an increase in the basal friction. In the case of a rise in basal friction, a backthrust may be initiated, provided that the work necessary to crosscut the sedimentary layers and further activate the basal thrust below the intercutaneous wedge is less than the work needed to propagate the floor thrust to the foreland [Jamison, 1993].

[38] The curved deformation front of the Jura coincides with the north and west outer boundary of the salt basin. It should be noticed that salt is also found more to the west of the Jura front in the Bresse graben, but this part of the salt basin was not involved in Miocene compressive deformations since it was downthrown by normal faults in Oligocene (see section 2). The outermost displacement vectors are generally perpendicular to the edge of the salt basin which disappears due to tectonic offset or stratigraphic pinch out. The divergence of the outermost displacement vectors is then clearly related to the heterogeneity of the décollement zone.

[39] Another interesting feature that characterizes the Jura displacement field is the displacement gradient along the lines of transport or "flow lines." Six curved transects of the displacement field have been drawn along the arc. The result is shown on Figure 10 as the relation between displacements and the distance from the trailing reference point along each transect. The relation between displacement and thickness of the décollement level is evident. The striking feature is that except for transect 6 (the westernmost) the evolution of displacement is not linear. The shape of the curves can be correlated with the deformation 
domains. For example, in the southeastern part of transects 3, 4 and 5, a flat is observed which corresponds to the effect of the nearly undeformed molasse basin that was transported passively with little deformation. Another flat is observed on transects 2 and 3 and corresponds to the rigid translation of the Jura "Plateaux." The effect of the frontal thrust (transects 3, 4 and 5) is also worth noting.

[40] Finally, having evaluated displacements and knowing the timing of deformation, an attempt was made to evaluate the shortening strain rate. As our knowledge of the chronology of deformation is limited to the fact that deformation propagated forelandward from 15 Ma to $6 \pm$ $3 \mathrm{Ma}$ [Affolter, 2003; Becker, 2000], the duration of deformation is only known for the trailing part of the arc. So the calculation was made for the trailing part only, by comparing the displacement vector $(\Delta \mathrm{l})$ with the length of the transect (1). These $\Delta 1 / 1$ shortening values range from 0.17 to 0.24 . A mean value of 0.2 was taken and the natural strain rate [Pfiffner and Ramsay, 1982] was determined, which is the mean strain rate during a progressive deformation when assuming a steady deformation of rocks. A value very close to $10^{-15} \mathrm{~s}^{-1}$ was found that is representative of a geological strain rate value.

\section{Conclusions}

[41] Surface restoration of a detailed 3-D model of the Jura fold-thrust belt was aimed at understanding the mechanism of formation of an arcuate orogen. An UNFOLD flexural-slip numerical method was used so as to integrate displacements related to thrusting, folding and strike-slip faulting. Such a numerical restoration technique used at a regional scale proves to be an efficient tool for reconstructing the cumulative effect of tectonic deformations over geological periods of time. The validity of such a restoration depends on the accuracy of the model in the deformed state and therefore on our ability to identify geological structures. The quality of the restoration gives an indication on the internal consistency of the 3-D model. The retrodeformation yielded a detailed displacement field characterized by (1) unidirectional displacements for the innermost vectors, (2) fanning displacement trajectories which end up perpendicular to the front range in agreement with field observations, (3) smoothly changing displacement directions (except across major strike-slip faults where the variation in the magnitude of displacements can be up to $9 \mathrm{~km}$ ), (4) a progressive increase in displacements from the lateral arc terminations toward its axis of symmetry, resulting in clockwise-anticlockwise rotations of the arc trailing line of $10^{\circ}$ and $18^{\circ} \mathrm{NE}$ and $\mathrm{SW}$ of the symmetry axis, respectively, (5) substantial rigid body rotations of both arc inner limbs $\left(10^{\circ}\right.$ clockwise and $30^{\circ}$ anticlockwise for the NE and SW limbs of the inner arc, respectively, but only $18^{\circ}$ anticlockwise for the trailing line in the SW because $12^{\circ}$ out of the $30^{\circ}$ are taken up by the Bauges front), and (6) an arc parallel extension accommodated by strike-slip faults always strongly oblique $\left(>60^{\circ}\right)$ to thrusts and folds.

[42] The Jura arc is a complex fold-thrust belt that presents most of the characteristics of a divergent displacement arc in its external part and features of a parallel displacement arc in its most internal part. This transition could be due to a link between the Jura and an Alpine indenter characterized by a parallel displacement field [Affolter, 2003]. The arcuate shape of the Jura is linked to initial distribution of the décollement horizon (salt layers). The outermost displacement vectors are everywhere perpendicular to the boundaries of the salt basin which correspond to a tectonic offset or a stratigraphic pinch out. The divergence of the outermost displacement vectors is then attributed to the spatial distribution of the décollement horizon. A comparison with GPS data documenting ongoing displacement in arcuate collisional belts indicates that a divergence of displacements toward the curved front of deformation is a common mechanism of arc formation.

[43] Finally, a detailed analysis of displacement gradients shows their relation with deformational domains and basal friction properties. A mean natural strain rate value of $\sim 10^{-15} \mathrm{~s}^{-1}$ is estimated which seems representative along the arc.

[44] Acknowledgments. Thomas Affolter was supported by a Ph.D. grant from the French Petroleum Institute and the French State. Visualization of the 3-D model was done using the Gocad software, and we thank the Earth Decision Sciences company for providing us a free license of it in Grenoble. We wish to thank Isabelle Manighetti, David Hindle, and Robin Lacassin for their thoughtful reviews. We are grateful to our colleagues at the IFP and LGIT for valuable discussions. Special thanks to Martin Burkhard, professor at the University of Neuchâtel, who provided helpful documents to build the Swiss part of the 3-D model.

\section{References}

Affolter, T. (2003), Etude des déformations et restauration 3D d'un bassin de front de chaîne: L'exemple du Jura et des Massifs Subalpins français, Ph.D. thesis, 150 pp., Joseph Fourier Univ., Grenoble, France.

Alabouvette, B., C. Cavelier, and N. Trauth (1984), Paléogène: Jura, in Synthèse Géologique du Sud-Est de la France, edited by M. J. Lienhardt, Mem. BRGM, 125(1), 354-362.

Argand, E. (1924), La tectonique de l'Asie, in Congrès Géologique International. Extrait du Compte-Rendu du XIIIe Congrès Géologique International, pp. 171-372, Brussels.

Audibert, M. (1990), Déformation discontinue et rotations de blocs. Méthodes numériques de restauration. Application à la Galilée, Ph.D. thesis, Univ. de Rennes 1, Rennes, France.

Becker, A. (2000), The Jura Mountains: An active foreland fold-and-thrust belt?, Tectonophysics, 321, 381-406.

Besse, J., and V. Courtillot (1991), Revised and synthetic apparent polar wander path of the African, Eurasian, North American and Indian plates, and true ploar wander since $200 \mathrm{Ma}$, J. Geophys. Res., 96, 4029-4050.

Bitterli, T. (1988), Die Dreidimensionale Massenbilanz: Ein wichtiges Hilfsmittel zum Verständnis der regionalen Kinematik (Schuppenzone von Reigoldswil, Faltenjura), Eclogae Geol. Helv., 81, 415-431.

Brusset, S., P. Souquet, J. Déramond, J. C. Sibuet, S. K. Hsu, B. Deffontaines, and H. T. Chu (1999), Partition between collision and subduction accretionary prisms along an inherited transcurrent fault zone: New insights on the Taiwan fold and thrust belt, Tectonics, $18,546-558$.

Burbank, D. W., B. Engesser, A. Matter, and M. Weidmann (1992), Magnetostratigraphic chronology, mammalian faunas and stratigraphic evolution of the Lower Freshwater Molasse, Haute-Savoie, France, Eclogae Geol. Helv., 85, 399-431.

Burkhard, M., and A. Sommaruga (1998), Evolution of the western Swiss Molasse basin: Structural relations with the Alps and the Jura belt, in Foreland Basins of the Western Alpine Thrust Belts, edited by A. Mascle, Geol. Soc. Spec. Publ., 134, 279-298.

Butler, R. F. (1992), Paleomagnetism: From Magnetic Domains to Geologic Terranes, Blackwell Sci., Malden, Mass.

Buxtorf, A. (1907), Geologische Beschreibung des Weissenstein: Tunnels und seiner Umgebung, Beitr. Geol. Karte, 21.

Buxtorf, A. (1916), Prognosen und Befunde beim Hauensteinbasis und Grenchenbergtunnel und die Bedeutung der letzteren für die Geologie der Juragebirges, Verh. Naturforsch. Ges. Basel, 27, 185-254.

Carey, S. W. (1955), The orocline concept in geotectonics, Proc. R. Soc. Tasmania, 89, 255-288. 
Chauve, P., and J. Perriaux (1974), Le Jura, in Les chaînes plissées du cycle alpin et leur avant-pays, vol. 2, Géologie de la France, edited by J. Debelmas, pp. 443-464, Bur. de Rech. et Miner. Fr., Orléans, France. Chauve, P., R. Enay, R. Fluck, and C. Sittler (1980), Vosges, fossé Rhénan, Bresse, Jura, in 26ème Congrès Géologique International, Ann. Sci. Univ. Besançon, 4(1), 81-114.

Chauve, P., J. Martin, E. Petitjean, and F. Seiqueiros (1988a), Le chevauchement du Jura sur la Bresse. Données nouvelles et réinterprétation des sondages, Bull. Soc. Géol. Fr., IV, 861-870.

Chauve, P., J. Martin, E. Petitjean, and F. Sequeiros (1988b), Le chevauchement du Jura sur la Bresse. Données nouvelles et réinterprétation des sondages, Bull. Soc. Géol. Fr., IV, 861-870.

Cobbold, P. R. (1979), Removal of finite deformation using strain trajectories, J. Struct. Geol., 1, 67-72.

Cobbold, P. R., and M. N. Percevault (1983), Spatial integration of strains using finite elements, J. Struct. Geol., 5, 299-305.

Colletta, B., M. C. Cacas, and R. Vially, and J.-C. Lecomte (2002), Southern Jura Petroleum System, IFP, Rueil-Malmaison, France.

Dahlstrom, C. D. A. (1970), Structural geology in the eastern margin of the Canadian Rocky Mountains, Bull. Can. Pet. Geol., 18, 332-406. Deichmann, N. (1992), Structural and rheological implications of lowercrustal earthquakes below northern Switzerland, Phys. Earth Planet. Inter., 69, 270-280.

Demarest, H. H. (1983), Error analysis for the determination of tectonic rotation from paleomagnetic data, J. Geophys. Res., 88, 4321-4328.

Deville, E., and A. Chauvière (2000), Thrust tectonics at the front of the western Alps: Constraints provided by the processing of seismic reflection data along the Chambéry transect, C. R. Acad. Sci., Ser. IIa, 331, $725-732$

Deville, E., E. Blanc, M. Tardy, C. Beck, M. Cousin, and M. Mènard (1994), Thrust propagation and syntectonic sedimentation in the Savoy Tertiary Molasse Basin (Alpine foreland), in Hydrocarbon and Petroleum Geology of France, edited by A. Mascle, Eur. Assoc. Pet. Geol. Spec. Publ., 4, 269-280, Springer-Verlag, New York.

Donzeau, M., R. Wernli, J. Charollais, and G. Monjuvent (1997), Notice explicative, Carte géologique France, scale $1 / 50,000$, feuille SaintJulien-en-Genevois (653), 144 pp., Bur. de Rech. Geol. Min., Orléans, France.

Doudoux, B., B. Mercier de Lepinay, and M. Tardy (1982), Une interprétation nouvelle de la structure des massifs subalpins savoyards (Alpes occidentales): Nappes de charriage oligocènes et déformations superposées, C. R. Acad. Sci., 295, 63-68.

Enay, R. (1982), Notice explicative de la feuille Saint-Rambert-en-Bugey à 1/50,000, 84 pp., Bur. de Rech. Geol. Min., Orléans, France.

Etchecopar, A. (1977), Plane kinematic model of progessive deformation in a polycristalline aggregate, Tectonophysics, 39, 121-139.

Ferrill, D. A., and R. H. Groshong (1993), Kinematic model for the curvature of the northern Subalpine Chain, France, J. Struct. Geol., 15, $523-$ 541.

Gehring, A. U., P. Keller, and F. Heller (1991), Paleomagnetism and tectonics of the Jura arcuate mountain belt in France and Switzerland, Tectonophysics, 186, 269-278.

Gidon, M. (1988), L'anatomie des zones de chevauchement du massif de la Chartreuse (Chaînes subalpines septentrionales, Isère, France), Géol. Alpine, 64, 27-48.

Gidon, M. (1990), Les décrochements et leur place dans la structuration du massif de la Chartreuse (Alpes occidentales françaises), Géol. Alpine, 66, $39-55$.

Gidon, M. (1996), Vues nouvelles sur la structure des massifs des Bornes et des Bauges orientales, Géol. Alpine, 72, 35-59.

Gratier, J.-P., and B. Guillier (1993), Compatibility constraints on folded strata and calculation of total displacement using computational restauration (UNFOLD program), J. Struct. Geol., 15, 1-14.

Gratier, J.-P., G. Ménard, and R. Arpin (1989), Strain-displacement compatibility and restoration of the Chaînes Subalpines of the western Alps, in Alpine Tectonics, edited by M. P. Coward, D. Dietrich, and R. G. Park, Geol. Soc. Spec. Publ., 45, 65-81.

Gratier, J.-P., B. Guillier, A. Delorme, and F. Odonne (1991), Restoration and balance of a folded and faulted surface by best-fitting of finite elements: Principle and applications, J. Struct. Geol., 13, 111-115.

Gratier, J.-P., T. Hopps, C. Sorlien, and T. Wright (1999), Recent crustal deformation in southern California deduced from the restoration of folded and faulted strata, J. Geophys. Res., 104, 4887-4899.

Heim, A. (1921), Geologie der Schweiz, 704 pp., Tauchniz, Leipzig, Germany.

Hilbert, D., and S. Cohn-Vossen (1952), Geometry and the Imagination, Chelsea, New York.

Hindle, D., and M. Burkhard (1999), Strain, displacement and rotation associated with the formation of curvature in fold belts: The example of the Jura arc, J. Struct. Geol., 15, 391-402.
Hindle, D., O. Besson, and M. Burkhard (2000), A model of displacement and strain for arc-shaped mountain belts applied to the Jura arc, J. Struct. Geol., 22, 1285-1296.

Hindle, D., J. Kley, E. Klosko, S. Stein, T. Dixon, and E. Norabuena (2002), Consistency of geologic and geodetic displacements during Andean orogenesis, Geophys. Res. Lett., 29(8), 1188, doi:10.1029/2001GL013757.

Homberg, C., J. C. Hu, J. Angelier, F. Bergerat, and O. Lacombe (1997), Characterization of stress perturbations near major fault zones: Insights from 2D distinct-element mumerical modelling and field studies (Jura Mountains), J. Struct. Geol., 19, 703-718.

Hu, J. C., S. B. Yu, J. Angelier, and H. T. Chu (2001), Active deformation of Taiwan from GPS measurements and numerical simulations, J. Geophys. Res., 106, 2265-2280.

Jamison, W. R. (1993), Mechanical stability of the triangle zone: The backthrust wedge, J. Geophys. Res., 98, 20,015-20,030.

Kadzialko-Hofmokl, M., and J. Kruczyk (1987), Paleomagnetism of middle-late Jurassic sediments from Poland and implications for the polarity of the geomagnetic field, Tectonophysics, 139, 53-66.

Kempf, O., F. Schlunegger, P. Strunk, and A. Matter (1998), Paleomagnetic evidence for late Miocene rotation of the Swiss Alps: Results from the north Alpine foreland basin, Terra Nova, 10, 6-10.

Lamb, S. (2000), Active deformation in the Bolivian Andes, South America, J. Geophys. Res., 105, 25,627-25,653.

Laubscher, H. P. (1961), Die Fernschubhypothese der Jurafaltung, Eclogae Geol. Helv., 54, 221-281.

Laubscher, H. P. (1965), Ein kinematisches Modell der Jurafaltung, Eclogae Geol. Helv. 58, 232-318.

Laubscher, H. P. (1972), Some overall aspects of Jura dynamics, Am. J. Sci., 272, 293-304.

Macedo, J., and S. Marshak (1999), Controls on the geometry of fold-thrust belt salients, Geol. Soc. Am. Bull., 111, 1808-1822.

Marshak, S. (1988), Kinematics of the orocline and arc formation in thinskinned orogens, Tectonics, 7, 73-86.

Martinod, J., D. Hatzfeld, J.-P. Brun, P. Davy, and P. Gautier (2000), Continental collision, gravity spreading and kinematics of the Aegea and Anatolia, Tectonics, 19, 290-299.

McClusky, S., et al. (2000), Global Positioning System constraints on plate kinematics and dynamics in the eastern Mediterranean and Caucasus, J. Geophys. Res., 105, 5695-5719.

Ménard, G. (1987), Coupe équilibrées crustales, méthodologie et applications aux Alpes externes: Un modèle cinématique, Geodin. Acta, 1, 35-45.

Michel, P., G. Appert, J. Lavigne, A. Lefavrais, A. Bonte, G. Lienhardt, and J. Ricour (1953), Le contact Jura-Bresse dans la région de Lons-le-Saunier, Bull. Soc. Géol. Fr., 6, 593-611.

Oertel, G. (1974), Unfolding of an anticline by the reversal of observed strains, Geol. Soc. Am. Bull., 85, 445-450.

Pavoni, N. (1977), An investigation of microearthquake activity in the central Valais (Swiss Alps), Publ. Inst. Geophys. Pol. Acad. Sci., 116, $317-320$.

Pfiffner, O. A., and J. G. Ramsay (1982), Constraints on geological strain rates: Arguments from finite strain states of naturally deformed rocks, J. Geophys. Res., 87, 311-321.

Philippe, Y. (1994), Transfer zone in the southern Jura thrust belt (eastern France): Geometry, development and comparison with analogue modelling experiments, in Exploration and Petroleum Geology of France, Eur. Assoc. of Pet. Geol. Mem., vol. 4, edited by A. Mascle, pp. 327-346, Springer-Verlag, New York.

Philippe, Y. (1995), Rampes latérales et zones de transfert dans les chaînes plissées: Géométrie, conditions de formation et pièges structuraux associés, Ph.D. thesis, Univ. de Savoie, Annency, France.

Ramsay, J. G., and M. Huber (1983), The Techniques of Modern Structural Geology, Academic, San Diego, Calif.

Ries, A. C., and R. M. Shackleton (1976), Patterns of strain variations in arcuate fold belts, Philos. Trans. R. Soc. of London, Ser. A, 283, $281-$ 288.

Rouby, D., P. R. Cobbold, S. P. S. Demercian, D. Cohelo, and J. A. Rici (1993), Least-squares palinspastic restoration of regions of normal faulting. Application to the Campos basin (Brazil), Tectonophysics, 221, $439-452$.

Sambeth, U., and N. Pavoni (1988), A seismotectonic investigation in the Geneva Basin, southern Jura Mountains, Eclogae Geol. Helv., 81, 433440.

Schwerdtner, W. M. (1977), Geometric interpretation of regional strain analysis, Tectonophysics, 39, 515-531.

Sommaruga, A. (1995), Geology of the Central Jura and the Molasse basin: New insight into an evaporite-based foreland and thrust belt, Mém. Soc. Neuch. Sci. Nat., XII.

Thouvenot, F., et al. (1998), The $M_{L} 5.3$ Epagny (French Alps) earthquake of 1996 July 15: A long-awaited event on the Vuache Fault, Geophys. J. Int., 135, 876-892. 
Tschanz, X., and A. Sommaruga (1993), Deformation associated with folding above frontal and oblique ramps around the rhomb shaped Val-de-Ruz basin (Jura Mountains), Ann. Tectonicae, VII, 53-70.

Vigny, C., et al. (2002), GPS network monitors the Western Alps' deformation over a five-year period: 1993-1998, J. Geod., 76, 73-76.

Wessel, P., and W. H. F. Smith (1995), The Generic Mapping Tools (GMT) version 3.0: Technical reference and cookbook, Sch. of Ocean and Earth Sci. and Technol. Univ. of Hawaii, Honolulu.

Wilkerson, M. S., D. A. Medwedeff, and S. Marshak (1991), Geometrical modeling of fault-related folds: A pseudo-three-dimensional approach, J. Struct. Geol., 13, 801-812.
Wilkerson, M. S., T. Apotria, and T. Farid (2002), Interpreting the geological map expression of contractional fault-related fold terminations: Lateral/oblique ramps versus displacement gradients, J. Struct. Geol., 24, $593-607$.

T. Affolter, Treches 2, CH-2017 Boudry, Switzerland. (affolter.thomas@ bluewin.ch)

J.-P. Gratier, LGIT IRIGM, BP 53X, F-38041 Grenoble, France. (jean-pierre.gratier@1git.obs.ujf-grenoble.fr) 